\title{
Hydrolytic Proteins of Sugarcane: The Q Enzyme
}

\author{
Alex G. Alexander ${ }^{1}$
}

\section{INTRODUCTION}

It is generally accepted that the two major components of starch are the straight-chain polysaccharide "amylose", and the highly branched polysaccharide "amylopectin". Early investigators of the starch-forming mechanism were perplexed by the prolific branching of the polysaccharide chains. The phosphorylase discovered in muscle by Cori and coworkers $(6,7)^{2}$, and in higher plants by Hanes $(11,12)$, catalyzes the synthesis of a straightchain polymer only, which is linked through $\alpha, 1-4$ glucosidic bonds. The starch-phosphorylase reaction thus could not in itself account for the multitude of $\alpha, 1-6$ glucosidic linkages characteristic of amylopectin.

More recently, a branching enzyme has been obtained from potato extracts which acts in conjunction with starch phosphorylase to form a branched polysaccharide of the amylopectin type $(10,17)$. This catalyst has been named the "Q enzyme". The $Q$ enzyme apparently acts as a transglucosidase by transferring relatively short portions of a long, 1 to 4 linked amylose chain to the number 6 hydroxyl group of glucose units within the chain. In effect, the 1 to 4 linked amylose chain is shortened and extensive branching in brought about through 1 to 6 linkages ${ }^{3}$.

Although the straight-chain amylose of both starch and glycogen gives a deep blue color with iodine, we have found that the starch phosphorylase of sugarcane yields a product forming a blue-violet color with iodine. According to Meyer (16) this blue-violet color is typical for branched polysaccharides. A branching factor in sugarcane would serve an essential role in the process of starch formation, and thus would become a potentially limiting factor in the diversion of glucose-1-phosphate from sucrose-forming pathways. A series of experiments was therefore initiated to determine whether the $Q$ enzyme was present in sugarcane, and, if so, to determine its characteristic properties. This paper presents a report on a Q-enzyme, $\alpha$-amylase complex encountered in sugarcane-leaf extracts.

${ }_{1}^{1}$ Associate Plant Physiologist, Agricultural Experiment Station, University of Puerto Rico, Río Piedras, P.R.

2 Italic numbers in parentheses refer to Literature Cited, p. 203.

"The terms "hydrolytic" and "hydrolysis" are employed throughout this paper in reference to the action of $Q$ enzyme, and are based upon the assumption that the scission of $\alpha, 1-4$ linkages takes place by the addition of the elements of water. This view is contested by Peat (17). 


\section{EXPERIMENTAL PROCEDURE}

\section{PREPARATION OF ENZYME}

Enzyme preparations were made with distilled-water extracts of lyophilized leaf tissue from 4-month-old sugarcane of the variety M.336. The basal 14 inches of leaves +1 to +4 were frozen in a mixture of Dry Ice (solid $\mathrm{CO}_{2}$ ) and acetone. The leaves were then freeze-dried at $2^{\circ} \mathrm{C}$. and ground to pass a 60-mesh screen. The powdered tissues were sealed in sample jars and stored at $-20^{\circ} \mathrm{C}$.

The original evidence of $\mathrm{Q}$ enzyme was observed while working with a dialyzed protein precipitate obtained by bringing leaf extracts to 95 -percent saturation with ammonium sulfate. During the present study, we adapted the Q-enzyme isolation procedures of Barker et al. (4), which had been used for characterizing the $Q$ enzyme of potato. This procedure involves the precipitation of protein from the plant extract by lead acetate at $\mathrm{pH}$ 7.2, followed by the elution of the precipitate with bicarbonate in the presence of $\mathrm{CO}_{2}$, and the subsequent fractionation of the supernatant liquid with neutral ammonium sulfate. Barker and coworkers obtained several protein fractions in this manner $\left(Q_{1}, Q_{2}\right.$, and $\left.Q_{3}\right)$, which contained $Q$ enzyme $\left(Q_{1}\right)$ and starch phosphorylase $\left(Q_{2}\right)$, in the presence of only traces of maltase and amylase. Fatty acids, which could have interferred with enzyme studies by forming insoluble complexes with amylose, were not present in these preparations.

The following procedure was developed for isolating $Q$ enzyme from freeze-dried leaf tissue of sugarcane: Forty grams of leaf powder were extracted for 1 hour with $325 \mathrm{ml}$. of distilled water. The extractions were carried out at $22^{\circ} \mathrm{C}$. and were facilitated with a mechanical shaker operating at slow speed. Tissue debris was removed by expressing the mixture through six layer's of absorbent gauze ( $20 \times 12 \mathrm{mesh}$ ). The suspension was clarified by centrifuge for 10 minutes at 3,500 r.p.m. Exactly $235 \mathrm{ml}$. of the supernatant liquid were adjusted to $\mathrm{pH} 7.0$ by adding $25 \mathrm{ml}$. of $0.04 \mathrm{~N} \mathrm{NaOH}$. Sixty milliliters of distilled water were added, followed by dropwise incorporation of $60 \mathrm{ml}$. of neutral lead acetate solution ( 0.16 molar), with constant stirring over a 10 -minute period.

The leaf-protein precipitate was removed by centrifuge at 3,000 r.p.m. and taken up in $200 \mathrm{ml}$. of $0.2 \mathrm{~N} \mathrm{NaHCO}_{3}$ solution. This suspension was stirred mechanically for 5 minutes, and a stream of $\mathrm{CO}_{2}$ was then passed through for an additional 5 minutes. The precipitate was again removed by centrifuge and at this time was discarded. To this point, the isolation procedure was identical with that of Barker el al. (4), and the $Q$ enzyme contained in the bicarbonate supernatant liquid could be removed by ammo- 
nium sulfate precipitation. It was now necessary to adapt our own fractionation procedure, and this will be discussed later in detail.

In order to study the $Q$ enzyme, it was essential that several other enzymes active in sugarcane be absent from the preparation. Phosphatase and amylase are particularly abundant in leaf tissues. Their presence was checked by methods described previously (1), as was the enzyme starch phosphorylase (2).

\section{ENZYME ASSAYS}

Q-enzyme activity was measured by following the loss of blue color when the substrate, soluble potato starch, was incubated in the presence of enzyme preparations. A potassium iodide-iodine ratio of $10: 1,0.5 \mathrm{mg}$. of potassium iodide and $0.05 \mathrm{mg}$. of iodine per milliliter, was employed to develop the color. Since the loss of blue color can also be brought about by amylase, it was necessary to measure simultaneously the reducing power of the reaction mixture in order to estimate the fraction of substrate being converted to maltose. This was accomplished by the dinitrosalicylic acid technique of Sumner (19).

The standard assay for $Q$ enzyme was conducted as follows: $1 \mathrm{ml}$. of $0.2 \mathrm{M}$ tris buffer-trishydroxymethylamino methane, $\mathrm{pH}$ 7.5-was placed in test tubes containing $1 \mathrm{ml}$. of additive or distilled water. One milliliter of substrate containing $4 \mathrm{mg}$. of soluble potato starch $^{4}$ was added, and the reaction was initiated by incorporating $1 \mathrm{ml}$. of enzyme preparation. At zero time and at intervals of 5 or 10 minutes thereafter, $0.25 \mathrm{ml}$. of the reaction mixture was withdrawn and transferred to a second set of test tubes containing $3.0 \mathrm{ml}$. of iodine solution. Simultaneously, $0.25 \mathrm{ml}$. of the reaction mixture was transferred to test tubes containing $3 \mathrm{ml}$. of dinitro reagent, and the latter was immediately placed in boiling water for color development. After 5 minutes, the tubes were cooled and reducing sugar was determined colorimetrically with the aid of a standard curve representing 0.01 to $0.25 \mathrm{mg}$. of maltose. The Q-enzyme analysis was usually continued for 50 minutes. The blue color, which was found to be quite stable, was measured after completing the assay by recording the optical density of the solutions at $580 \mathrm{~m} \mu$. The standard Q-enzyme assay was conducted at room temperature $\left(22^{\circ} \mathrm{C}\right.$.).

4 Stock solution of soluble starch was prepared as follows: Exactly $1 \mathrm{gm}$. of A.C.S.grade soluble potato starch was placed in a $200-\mathrm{ml}$. pyrex culture tube. The starch was wetted with $5 \mathrm{ml}$. of ethanol and taken up in $50 \mathrm{ml}$. of $0.5 \mathrm{~N} \mathrm{NaOH}$. Complete solution was accomplished by allowing the tube to stand in boiling water for 3 minutes. The starch solution was then adjusted to $\mathrm{pH} 7.0$ with $0.5 \mathrm{~N} \mathrm{H}_{2} \mathrm{SO}_{4}$, and brought to $100-\mathrm{ml}$. volume. One milliliter of stock solution contained $10 \mathrm{mg}$. of soluble starch, and dilutions were prepared accordingly as needed. The stock preparation was stable for about 48 hours. 


\section{DEFINITION OF TERMS}

It is essential that certain concepts and terms be defined before proceeding with problems of starch transformation. First, the reader should note that the substrate for these studies was soluble potato starch rather than pure amylose. The $\beta$-amylase conversion limit for soluble starch is 57 percent (18), or in other words, the straight-chain amylose fraction represents 57 percent, and the branched amylopectin 43 percent of the substrate in each reaction mixture. The amylose fraction accounts for the deep blue color of the starch-iodine complex. This color, under carefully prescribed conditions, is specific for the polysaccharide used as substrate, and has been defined as "blue value" (B.V.) by Bourne et al. (5). The B.V. employed throughout this paper diverges from that of Bourne and coworkers in that: 1 , A different wavelength was employed $\left(580 \mathrm{~m} \mu\right.$ rather than $\left.6,800_{\mathrm{A}}\right) ; 2$, a different optical instrument was employed, a Beckman Model B Spectrophotometer rather than a Spekker Photoelectric Adsorptionmeter; and 3 , we chose a more concentrated standard substrate solution $(0.25 \mathrm{mg} . / \mathrm{ml}$. rather than $1 \mathrm{mg} . / 100 \mathrm{ml}$.), which gave us a standard B.V. optical density reading of 0.690 , as compared with 0.189 (18).

In addition to B.V., another term often used is "absorption value", or A.V. This term has been defined by Bourne et al. (5), and refers to the reading on the logarithmic scale of a Spekker Photoelectric Adsorptionmeter when measuring light adsorption by a polysaccharide-iodine solution contained in 4-cm. cells. Neither the substrate concentration nor the wavelength is rigidly defined for A.V., and the usual procedure is to state the wavelength along with the reading for a given solution, i.e., A.V. = $0.53\left(6,800_{\Lambda}\right)$. Previous workers often used the terms B.V. and A.V. to describe the branching action of $Q$ enzyme on amylose, which causes a decrease in blue color, by adopting the expression "A.V. as percentage of original B.V.". This is a direct expression of the rate of color decline caused by enzyme action, since B.V. is itself a standardized A.V. which has not come under the influence of enzyme. The same expression is employed herein to describe the action of $Q$ enzyme.

Finally, the expression "percentage converted to maltose" will also appear consistently wherever a series of Q-enzyme values has been recorded. The expression is concerned only with the action of contaminating amylase, and refers to the percentage of the total starch which has been converted to maltose.

\section{ELECTROPHORESIS ANALYSES}

Enzyme preparations were examined electrophoretically with the aid of a Beckman Model $R$ paper electrophoresis system. Components of the system 
include a Durrum-type cell equipped with platinum-wire electrodes, a duostat to regulate power supply to the cell, and an analytrol used to scan, record, and integrate the optical density of developed paper strips. The general principle of the Durrum system is to separate by zone electrophoresis the components of a test solution along nonhorizontal paper strips suspended in an inverted- $V$ position within the saturated atmosphere of an enclosed cell.

Enzyme preparations were dialyzed for 10 hours prior to analysis by electrophoresis. In order to concentrate the protein sufficiently, the enzyme preparation $(4 \mathrm{ml}$.) was frozen, lyophilized, and the dried powder redissolved in $0.2 \mathrm{ml}$. of distilled water. Approximately $2.0 \mathrm{mg}$. of protein were spotted per strip. Buffer solution of $\mathrm{pH} 8.6$ and ionic strength of 0.075 was employed for the electrophoresis analyses of the present study. Each separation was run for 8 or 16 hours at $22^{\circ} \mathrm{C}$. with a constant current supply of $15 \mathrm{ma}$.

At the completion of each run, the strips were oven-dried, prerinsed in ethanol, dyed with bromphenol blue, and rinsed in 5-percent acetic acid to remove dye not absorbed by protein. The strips were again dried and color was developed by exposure to ammonia vapors. Each strip was scanned with the Model RB Analytrol, equipped with $500-\mathrm{m} \mu$ interference filters and a B-5 cam designed to correct for scanner light-energy distribution and inhomogenity of filter papers.

It soon became apparent that the $Q$ enzyme was highly unstable in solution, with activity declining markedly after 24 hours, even while under refrigeration. Barker et al. (4) encountered the same difficulty with the potato enzyme. They solved the problem by freeze-drying a stock of the enzyme solution, and utilizing the dried powder to prepare fresh solutions when needed. We elected to prepare the enzyme fresh daily.

\section{RESULTS AND DISCUSSION}

EXISTENCE OF A Q-ENZYME, ACID-AMYLASE COMPLEX IN CANE-LEAF EXTRACTS

Barker et al. (4) added neutral ammonium sulfate solution to the bicarbonate supernatant liquor described above, and precipitated the $Q$ enzyme in the fraction containing an equivalent of $19 \mathrm{gm}$. of ammonium sulfate in $100 \mathrm{ml}$. of solution $\left(Q_{1}\right)$. Further increase of ammonium sulfate to an equivalent of $35.0 \mathrm{gm}$. in $100 \mathrm{ml}$. yielded the $P$ enzyme (starch phosphorylase) in fraction $Q_{2}$. However, the same procedure with sugarcane-leaf extracts gave a $Q_{1}$ fraction with little activity of any kind, and a $Q_{2}$ fraction containing powerful amylase and phosphatase, as well as starch phosphorylase.

We considered that, if a branching enzyme were present in sugarcane, 
with properties similar to those of the potato enzyme, then this system should also be precipitated by lead acetate and removed through bicarbonate elution. It follows that during the salt-fractionation procedures, a preponderance of phosphatase and amylase would alter the point at which the specific protein-protein interaction exceeds the protein-water interaction (i.e., the saturation point at which $Q$ enzyme begins to precipitate). With this in mind we proceeded to salt out the predominate bulk of protein from the bicarbonate solution, between 0 and 95 -percent saturation, and to test this preparation for Q-enzyme activity.

A standard digest, assayed according to procedures outlined above, revealed a strong, multiple-amylase action, or in other words, more of the

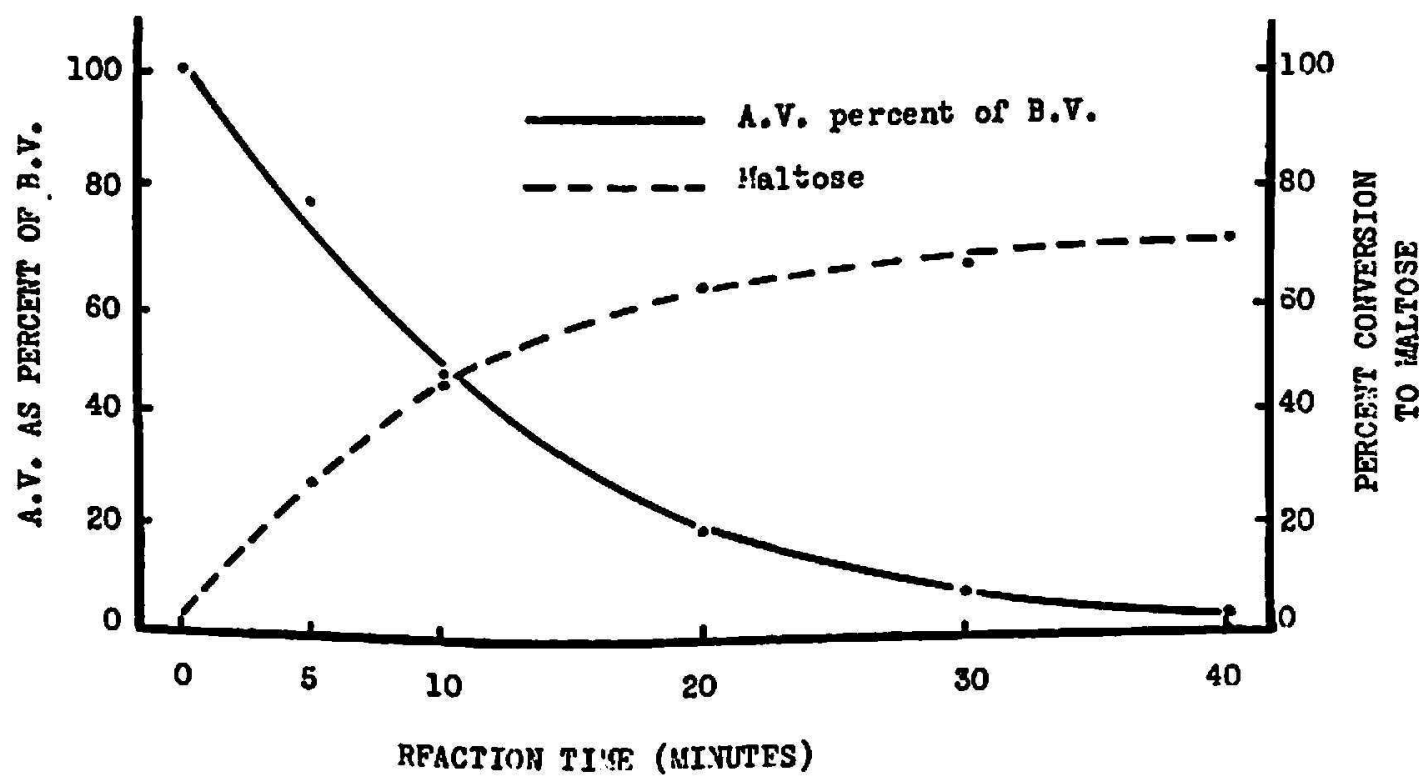

FIa. 1.-Starch hydrolysis by cane-leaf enzymes precipitated from bicarbonate extracts by 95 -percent suturation with ammonium sulfate.

substrate was converted to maltose than could be attributed to $\beta$-amylase activity upon the amylose fraction (fig. 1). While certainly suggesting that amylase systems were hydrolyzing both branched and unbranched polysaccharide, the experiment did not disprove the presence of $Q$ enzyme, i.e., that new branches were being formed in the face of amylase activity. Furthermore, the initially blue starch-iodine color remained a blue-violet at the end of the experiment, indicating that a net increase of branches had taken place during the reaction.

In order more conclusively to demonstrate the presence of $Q$ enzyme, the bicarbonate preparation was fractionated into increments of 5-percent saturation with ammonium sulfate. Each increment was tested for enzyme activity with the objective of isolating a strong starch-hydrolyzing power which was distinct from the action of amylase, phosphatase, and starch 
phosphorylase. The results of these tests are illustrated in figures 2, 3, and 4. Phosphatase was precipitated over a broad range of 45- to 75-percent saturation (fig. 2). Starch phosphorylase was precipitated between 35- and 40-percent saturation, and again between 80- and 90-percent saturation (fig. 3), suggesting that at least two phosphorylases were being measured.

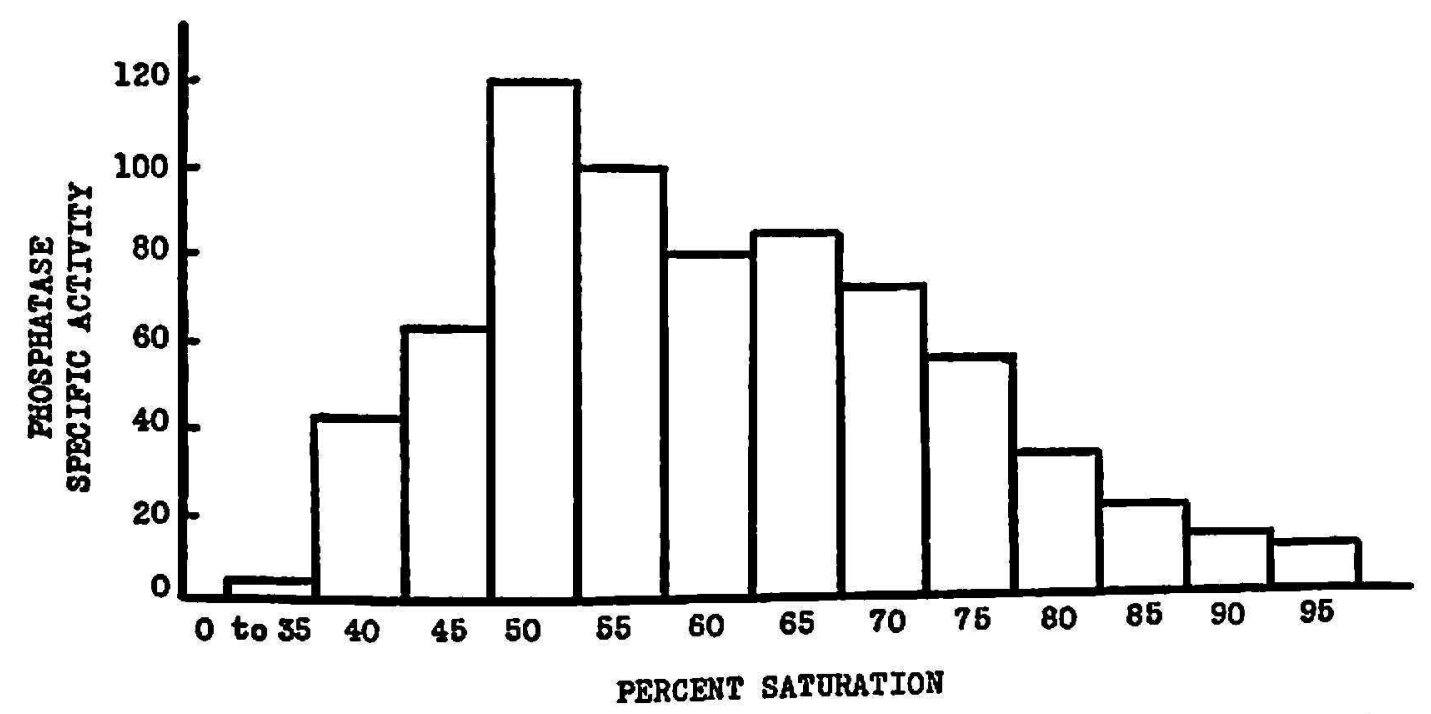

FIG. 2.-Acid phosphatase activity among protein fractions precipitated from bicarbonate extracts at 5-percent increments of ammonium sulfate saturation.

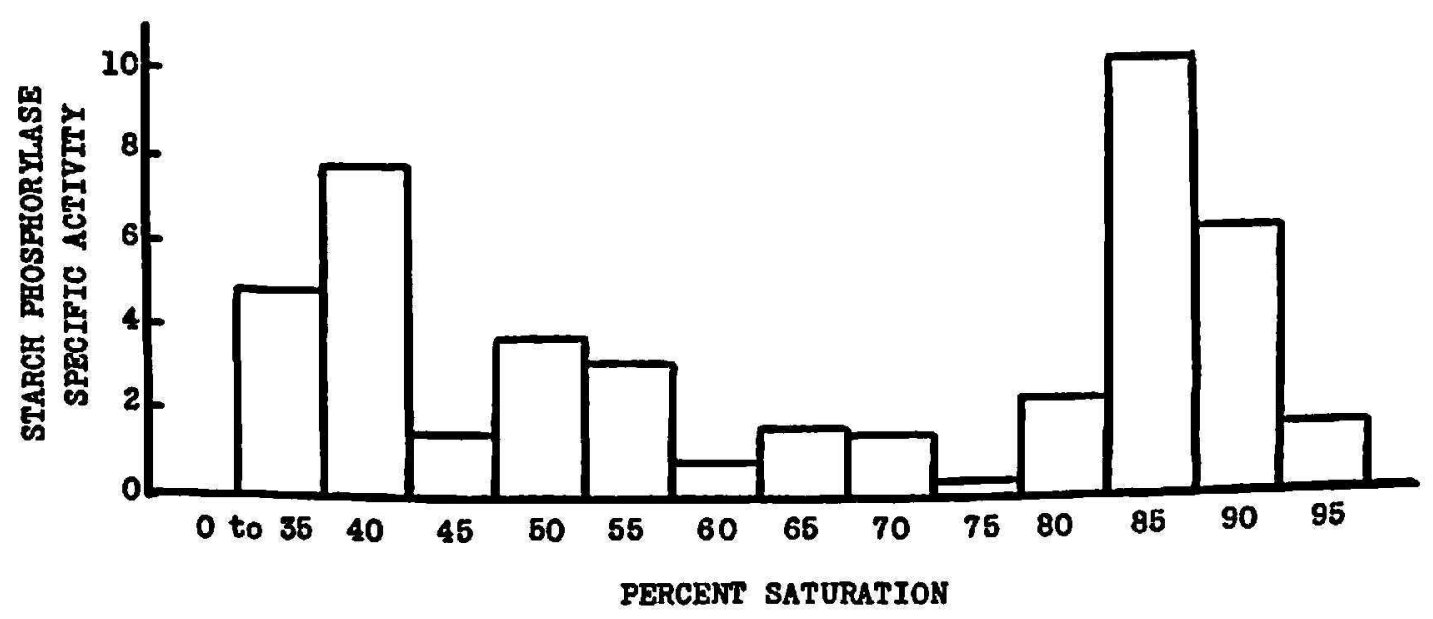

FIG. 3.-Starch-phosphorylase activity among protein fractions precipitated from bicarbonate extracts at 5-percent increments of ammonium sulfate saturation.

Of most concern to us was the enzyme $\beta$-amylase, which was determined according to the amount of maltose formed from a 1-percent solution of soluble starch. Amylase was removed primarily between 50 - and 60-percent saturation (fig. 4). Tests for the enzymatic suppression of the blue starchiodine color (B.V.) also showed strong activity in the area of 50- to 60percent saturation, but in addition, the color was readily dissipated by protein of the 0 to 35 -percent fraction. This was an area in which phospha- 
tase, starch phosphorylase, and amylase had appeared in trace amounts only.

The standard test for $Q$ enzyme was conducted with $1 \mathrm{ml}$. of undialyzed enzyme prepared from the 0 to 35 -percent precipitate ${ }^{5}$, and the results are illustrated by figure 5 . It is clear that the 0 to 35 -percent preparation possessed a strong capability to hydrolyze starch under the prescribed conditions of the assay. Q enzyme appeared to be totally dominant. Phosphatase activity was nil, and starch phosphorylase was too weak to be of consequence. The 0 to 35-percent fraction was therefore employed for the characterization experiments during the remainder of the study.

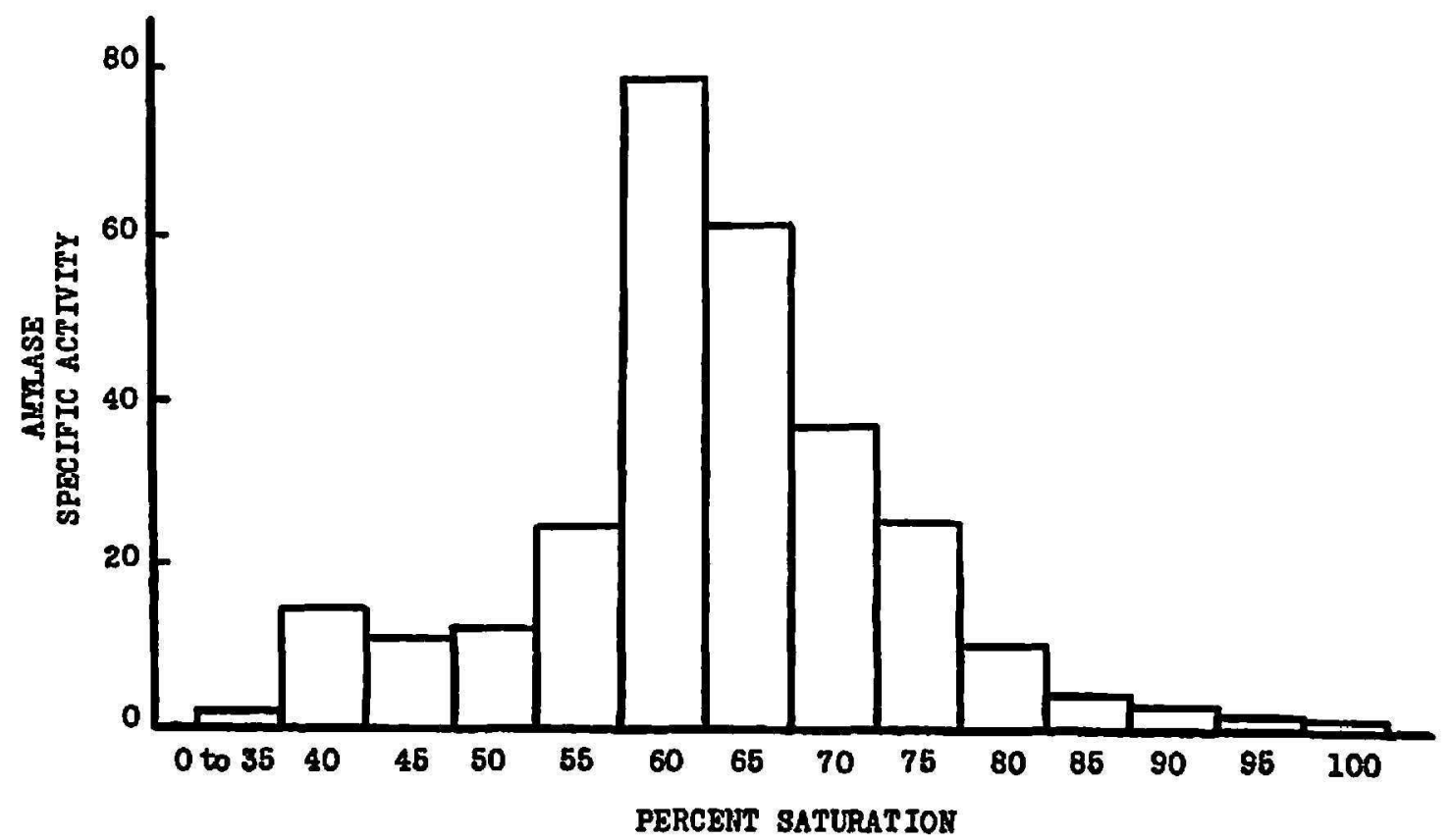

Frg. 4.-Amylase activity among protein fractions precipitated from bicarbonate extracts at 5-percent increments of ammonium sulfate saturation.

For the reader unfamiliar with enzymatic transformations of starch, the above reactions can be clarified by reference to figure 6 . The loss of the blue starch-iodine color can be accounted for 1 , by the hydrolysis of amylose via $\beta$-amylase, or 2 , by the formation of occasional side-branches along the previously straight chain. The latter transformation is catalyzed by $Q$ enzyme, and is also hydrolytic in the sense that elements of water are added during the breaking of $\alpha, 1-4$ linkages, i.e., during the hydrolysis of amylose into segments for transfer to number 6 hydroxyl groups. The color of the

${ }^{5}$ The protein of this fraction was removed by centrifuge immediately after the added salt had dissolved. The residue was taken up in $4 \mathrm{ml}$. of distilled water and recentrifuged to remove traces of lead precipitate which had been retained by the original bicarbonate supernatant. This solution was employed only for the remainder of that day, and was kept under refrigeration at all times. 


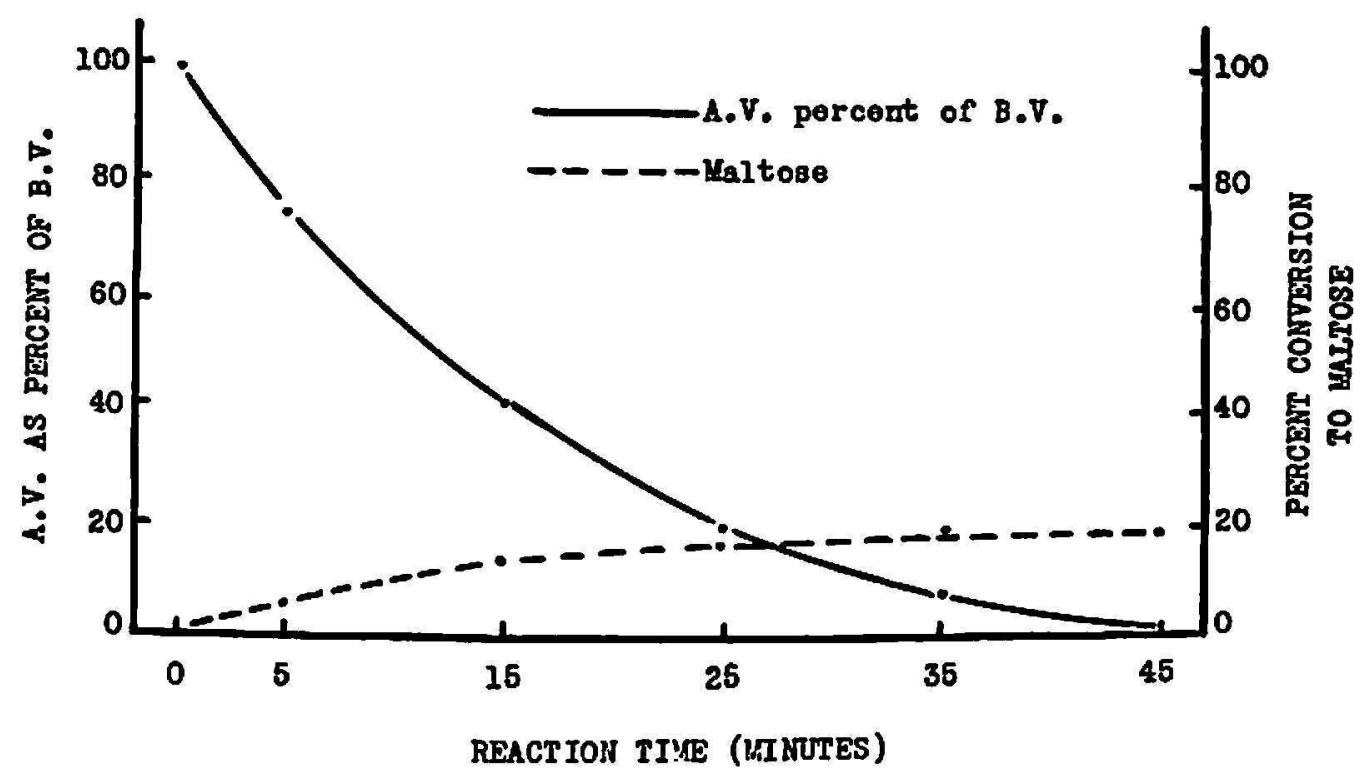

FIG. 5.-Hydrolysis of starch by leaf protein precipitated from bicarbonate extracts at between 0 and 35-percent saturation with ammonium sulfate.

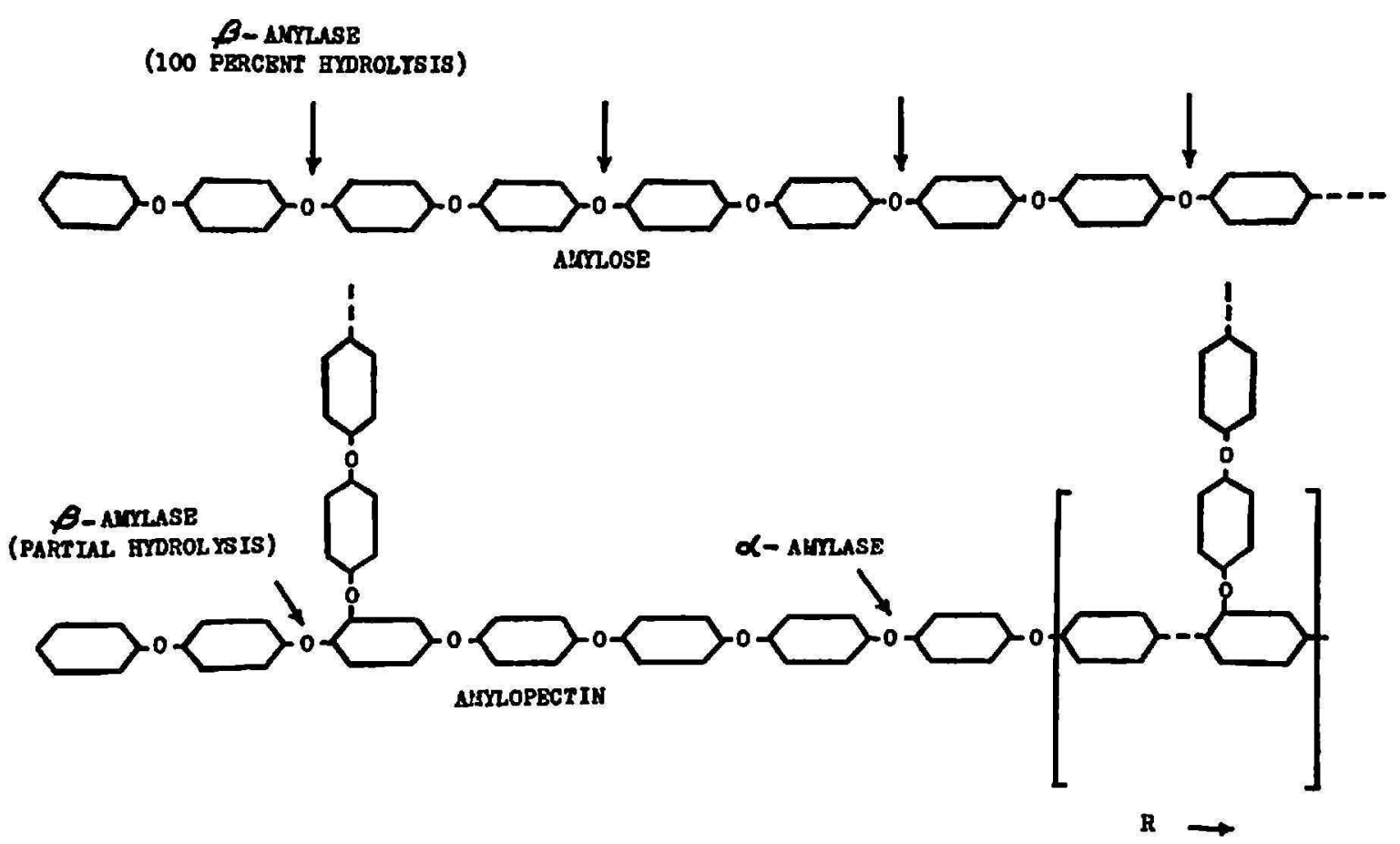

Fia. 6.-Hypothetical arrangement of the glucose residues of amylose and amylopectin. Regarding enzymatic hydrolysis, the following points are illustrated: $1, \mathrm{Al}-$ ternate sites of attack by $\beta$-amylase upon amylose to yield the disaccharide maltose; 2 , the limited action of $\beta$-amylase upon amylopectin due to the presence of side branches; and 3, the action of $\alpha$-amylase upon 1-4 glucosidic linkages in the interior of the amylopectin structure. 
polysaccharide-iodine complex passes from blue to blue-violet, to violet, and finally to brown, as the degree of branching increases $(16)^{6}$.

Figure 5 illustrates that the amylose fraction was transformed within 45 minutes, and that a maximum of only 35 percent of this fraction was converted to maltose. Theoretically, sufficient side-branches were formed via $\mathrm{Q}$ enzyme to block $\beta$-amylase while adsorption values continued to decline.

One point continued to plague us. The amylase activity of the 0 to 35 percent preparation seemed far too high. Furthermore, the amylase which we had assayed among the different increments, and which we had been diligently measuring in numerous past experiments, was virtually nonexistent in the 0 to 35-percent fraction. During the course of this study it became apparent that a totally different and hitherto unsuspected amylase was present in the Q-enzyme preparation. This fact was most vividly pointed up during the variable $\mathrm{pH}$ experiments.

\section{RESPONSE OF Q-ENZYME PREPARATION TO VARIABLE pH}

Activity of the branching enzyme was measured with a series of buffers ranging from $\mathrm{pH} 4$ to 9 (table 1 ). The activity curves illustrated by figure 7 indicate that the substrate was most readily hydrolyzed at $\mathrm{pH} 4$, while enzyme activity was more restricted at $\mathrm{pH} 9$. However, an examination of A.V. and maltose values presented in table 1 shows that less than 8 percent of the substrate was acted upon by amylase at $\mathrm{pH} 9$, while over 60 percent was converted to maltose by amylase at $\mathrm{pH} 4$. The contaminating amylase was also highly active at $\mathrm{pH} 5$, but declined sharply as $\mathrm{pH}$ values approached 7. In effect, the branching enzyme was the least sensitive of the two systems to decreasing acidity. Q enzyme was totally dominant at pH 9.

The discovery of an acid amylase in the Q-enzyme preparation came as a definite surprise. We had recognized earlier (1) that a powerful amylase was active in sugarcane leaves, and, in fact, the voracious nature of this system had prompted us to begin a series of starch-transforming experiments which led to the present study. But this amylase possessed a $\mathrm{pH}$ optimum of 6.5, and, as pointed out above, was almost totally absent from the 0 to 35-percent fraction containing Q enzyme. Again, the Q-enzyme

\footnotetext{
- Another type of enzyme plays a hypothetical role in the starch transformations discussed above, namely, an enzyme specific for the hydrolysis of $\alpha, 1-6$ glucosidic bonds. Such catalysts are known in the intestinal tracts of higher animals $(14,15)$, and by acting as "debranching agents", they effectively complete a series of enzymatic reactions needed for the degradation of ingested amylopectins and glycogens to free glucose. Similar enzymes have been identified in extracts of beans and potatoes $(18,18)$, and have been named " $R$ enzymes". We have no evidence now that they occur in sugarcane.
} 
TABLE 1.-Effects of variable $p H$ upon rate of starch hydrolysis by $Q$-enzyme preparation 1

\begin{tabular}{|c|c|c|c|c|c|c|c|c|}
\hline \multirow{2}{*}{ pH } & \multirow{2}{*}{ Starch transformation² } & \multicolumn{7}{|c|}{ Results for indicated reaction time (minutes) } \\
\hline & & 0 & $\mathbf{s}$ & 10 & 20 & 30 & 40 & so \\
\hline \multirow[t]{2}{*}{4.0} & A.V. as percentage of $\mathrm{B} . \mathrm{V}$. & 100 & 59.2 & 17.5 & 3.7 & 1.2 & 0.8 & 0.8 \\
\hline & Percentage conversion to maltose & 0 & 6.5 & 25.0 & 31.0 & 37.4 & 51.3 & 62.6 \\
\hline \multirow[t]{2}{*}{5.0} & A.V. as percentage of B.V. & 100 & 71.0 & 18.5 & 3.5 & 2.5 & 2.0 & 2.0 \\
\hline & Percentage conversion to maltose & 0 & 10.5 & 21.6 & 32.1 & 43.4 & 50.5 & 54.7 \\
\hline \multirow[t]{2}{*}{6.5} & A.V. as percentage of B.V. & 100 & 74.0 & 41.5 & 21.5 & 10.0 & 4.5 & 3.0 \\
\hline & Percentage conversion to maltose & 0 & 6.5 & 15.8 & 18.4 & 22.9 & 25.0 & 31.1 \\
\hline \multirow[t]{2}{*}{7.0} & A.V. as percentage of B.V. & 100 & 79.0 & 40.0 & 23.0 & 10.5 & 5.0 & 3.5 \\
\hline & Percentage conversion to maltose & 0 & 3.9 & 9.2 & 14.5 & 23.7 & 23.9 & 30.3 \\
\hline \multirow[t]{2}{*}{7.5} & A.V. as percentage of B.V. & 100 & 70.9 & 45.4 & 26.4 & 12.7 & 6.8 & 4.5 \\
\hline & Percentage conversion to maltose & 0 & 3.9 & 8.9 & 14.5 & 17.4 & 25.0 & 26.3 \\
\hline \multirow[t]{2}{*}{8.0} & A.V. as percentage of B.V. & 100 & 90.0 & 58.0 & 40.0 & 27.0 & 15.5 & 11.5 \\
\hline & Percentage conversion to maltose & 0 & 2.6 & 5.8 & 10.5 & 13.2 & 15.8 & 16.1 \\
\hline \multirow[t]{2}{*}{9.0} & A.V. as percentage of B.V. & 100 & 76.4 & 72.7 & 68.2 & 50.9 & 41.8 & 33.6 \\
\hline & Percentage conversion to maltose & 0 & 0 & 1.6 & 3.2 & 8.9 & 9.5 & 8.9 \\
\hline
\end{tabular}

1 The reaction mixture was composed of $2 \mathrm{ml}$. of buffer, $1 \mathrm{ml}$. of starch solution containing $6 \mathrm{mg}$. of soluble starch, and $1 \mathrm{ml}$. of enzyme preparation. All assays were run at $22^{\circ} \mathrm{C}$.

${ }^{2}$ Refer to Experimental Procedure section pp. 177ff. for discussion of the terms A.V., B.V., and percentage conversion to maltose.

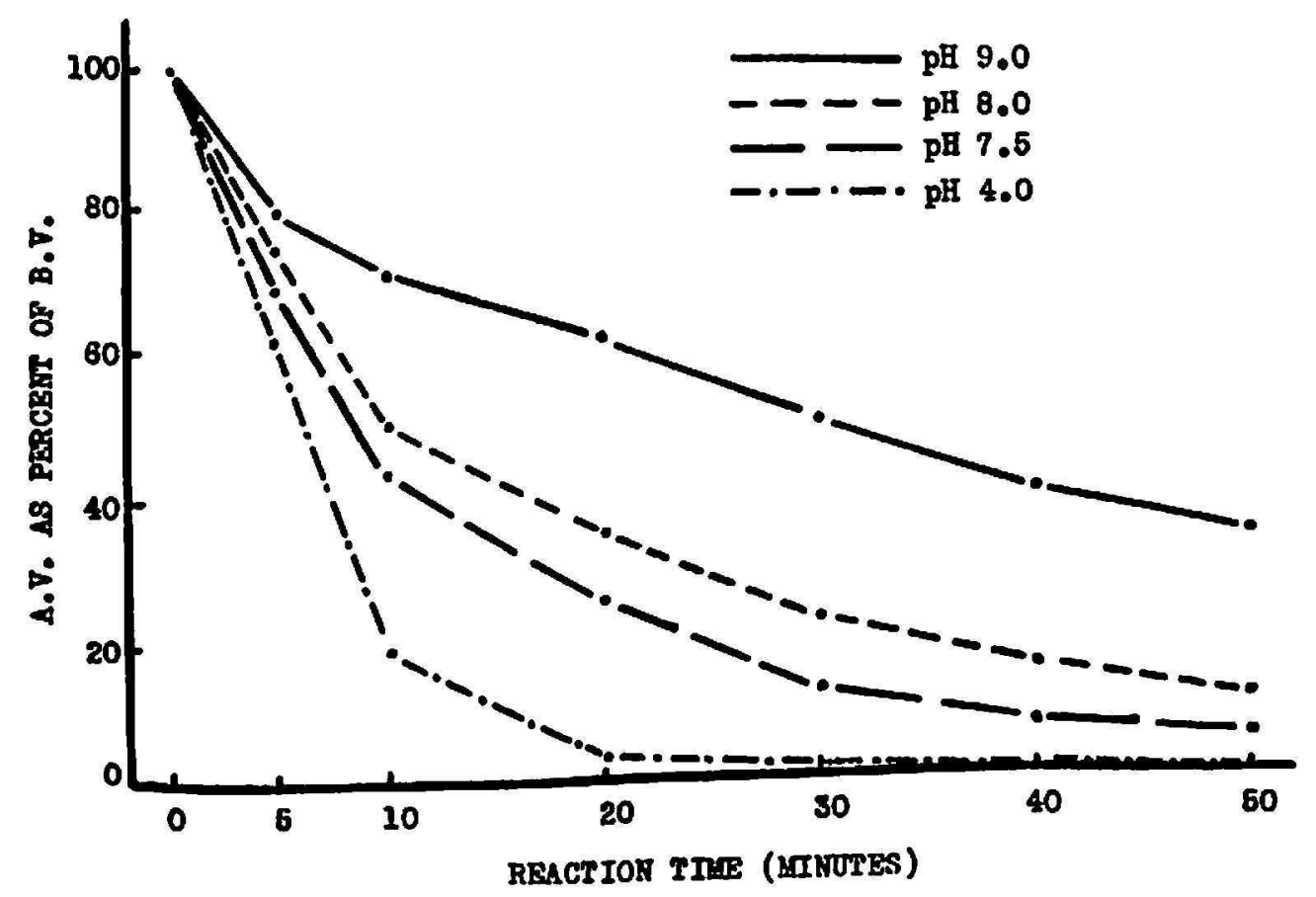

FIG. 7.-Effects of variable pH upon rate of blue-value decline in the presence of Q-enzyme preparation. 
extraction procedures we had employed were developed by workers who had for several years been trying to isolate the $Q$ enzyme free of amylase contamination. It is a curious phenomenon that starch-hydrolyzing mechanisms are at least as thoroughly entrenched in sugarcane, where starch is seldom encountered, as they are in the potato.

The $\mathrm{pH}$ experiments also revealed that the acid amylase was dependent upon a degree of branching by $Q$ enzyme before initiating its own action, or before its activity could be expressed through free maltose. For example, at $\mathrm{pH} 9$ only a trace of reducing sugar had appeared by 10 minutes, when the blue value had already declined by almost 27 percent (table 1 ). Conversely, at $\mathrm{pH} 4$ the amylose transformation was virtually complete by 20 minutes, the blue value having declined by 96.3 percent. At this time, 31 percent of the substrate had been converted to maltose, but the disaccharide continued to be formed during the subsequent 30 minutes until 62.6 percent of the original substrate had been converted to maltose. This means that during the latter half of the experiment, amylase was acting upon the starch fraction which had already been branched by $Q$ enzyme, as well as that which was branched prior to initiating the reaction. This unquestionably classifies the amylase as one of the $\alpha$ types: i.e., capable of acting upon $\alpha, 1-4$ linkages in the presence of side branches.

An additional experiment was conducted at pH 9 to clarify the Q-enzymeamylase relationship during a prolonged reaction period. It was theorized that an extended reaction period should favor the branching enzyme, if, in fact, the amylase were dependent upon an acid medium to approach its maximum product. The results are illustrated by figure 8 . The $Q$-enzyme preparation remained moderately active over a 220 -minute period, dissipating 94 percent of the original blue value. Amylase reached a peak of only 6-percent conversion to maltose at 80 minutes, and maltose had actually declined in the reaction mixture by 220 minutes. It is clear that the most favorable means of distinguishing between the two enzymes, short of physical separation, is by considering their extreme $\mathrm{pH}$ preferences. The $\mathrm{Q}$ enzyme tolerates a $\mathrm{pH}$ of 9.0 , but its optimum value lies in the area $\mathrm{pH}$ 7.5 to 8.0 (table 1).

At pH 9 (fig. 8) the $\mathrm{Q}$ enzyme followed a typical first-order response. The basic principle of the first-order plot is that for every equal interval of time, a certain constant fraction of the substrate undergoes reaction. In theory, infinite time would be required to complete such a reaction. The general form of the first-order equation is

$$
d x / d t=k^{1}(a-x)
$$

where $a$ is the initial substrate concentration, $x$ is the concentration of substrate converted, and $k^{1}$ is the first-order reaction rate constant. 
The purified enzyme of Gilbert and Swallow (9) obeyed a first-order equation in which the velocity constant was proportional to the slope of the reaction line. Within limits, the slope of the reaction line is proportional to the concentration of enzyme. The purified enzyme could therefore be measured in terms of the velocity constant, which can be calculated under standardized conditions from the time required to achieve a specific light absorption value. At pH 4 (fig. 7), the Q-enzyme-amylase complex deviates to a curve bearing a definite zero-order phase which, in turn, is a function of the contamination by $\alpha$-amylase.

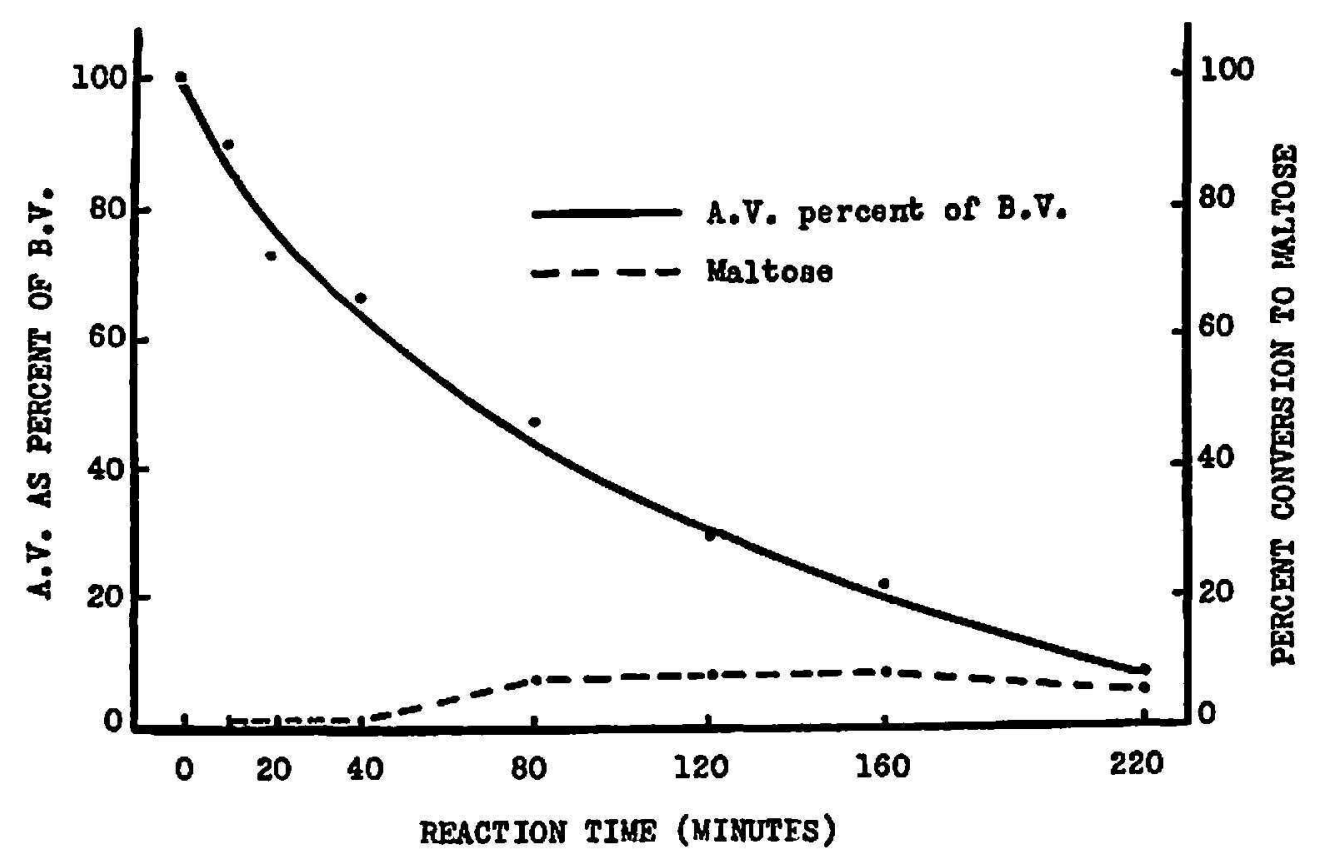

FIG. 8.-Prolonged hydrolysis of starch by Q-enzyme preparation at pH 9.

\section{EFFECTS OF VARIABLE SUBSTRATE CONCENTRATIONS}

The Q-enzyme preparation was tested with a series of substrate concentrations ranging from 0.5 to $2.5 \mathrm{mg}$. $/ \mathrm{ml}$. of digest (table 2). The optimum substrate concentration appeared to lie in the range of 2.0 to $2.5 \mathrm{mg} . / \mathrm{ml}$. where the substrate was not limiting at any time during the 50-minute reaction period. At $2.5 \mathrm{mg}$. $/ \mathrm{ml}$. the reaction could be plotted as a straight line (fig. 9), as contrasted with the typical first-order curves recorded with substrate values below $2.0 \mathrm{mg}$. $/ \mathrm{ml}$.

The measurements recorded in table 2 suggest that the hydrolytic reaction was most rapid against $0.5 \mathrm{mg}$. of substrate, and declined as the starch supply approached $2.5 \mathrm{mg}$. It should be pointed out that the activity figures are percentages rather than absolute turnover values, and that with a substrate supply of $2.5 \mathrm{mg}$./ $/ \mathrm{ml}$. the $\mathrm{Q}$ enzyme was transforming 2 to 3 times the quantity converted while acting upon $0.5 \mathrm{mg}$. The acid-amylase 
system remained more nearly constant as the substrate was increased, being suppressed slightly during the first 10 minutes of the reaction and stimulated slightly during the final 20 minutes. In effect, the higher starch

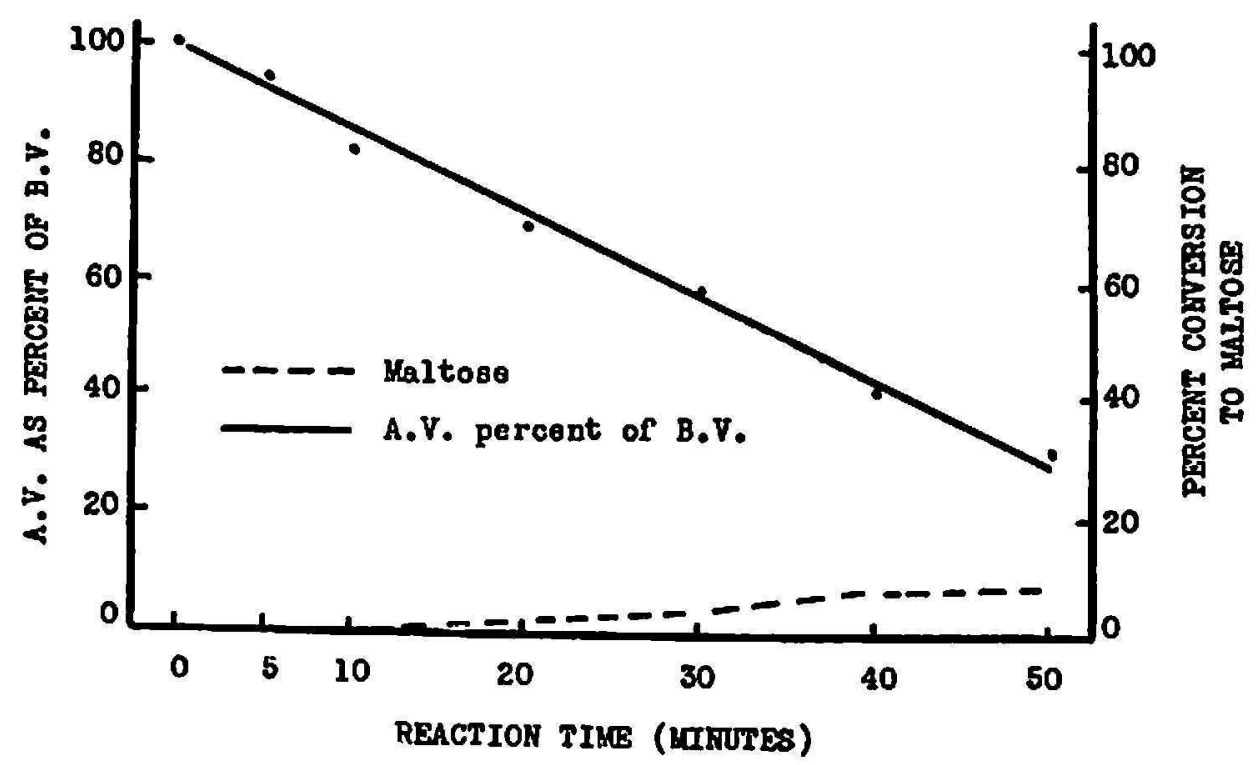

FIG. 9.-Activity of Q-enzyme preparation upon a substrate supply of $2.5 \mathrm{mg} . / \mathrm{ml}$. of digest.

TABLE 2.-Effects of variable substrate concentrations upon rate of slarch hydrolysis by Q-enzyme preparation'

\begin{tabular}{|c|c|c|c|c|c|c|c|c|}
\hline \multirow{2}{*}{$\begin{array}{l}\text { Substrate } \\
\text { (mg./ml.) }\end{array}$} & \multirow{2}{*}{ Starch transformation } & \multicolumn{7}{|c|}{ Results for indicated reaction time (minutes) } \\
\hline & & $\mathbf{0}$ & 5 & 10 & 20 & 30 & 40 & 50 \\
\hline \multirow[t]{2}{*}{0.5} & A.V. as percentage of B.V. & 100 & 85.7 & 57.1 & 41.7 & 17.5 & 11.1 & 7.9 \\
\hline & Percentage conversion to maltose & 0 & 11.2 & 14.4 & 22.2 & 23.0 & 24.6 & 27.2 \\
\hline 1.0 & $\begin{array}{l}\text { A. } V \text {, as percentage of } B . V \text {. } \\
\text { Percentage conversion to ma }\end{array}$ & 100 & 83.6 & 68.5 & 42.5 & 30.1 & 19.9 & 14.4 \\
\hline \multirow[t]{2}{*}{1.5} & A.V. as percentage of B.V. & $\begin{array}{r}0 \\
100\end{array}$ & 00.4 & 4.0 & 8.0 & 11.6 & 12.8 & 13.6 \\
\hline & Percentage conversion to maltose & 0 & $\begin{array}{r}90.9 \\
1.6\end{array}$ & $\begin{array}{r}78.2 \\
2.6\end{array}$ & 56.4 & 45.4 & 29.1 & $\begin{array}{l}21.8 \\
11.1\end{array}$ \\
\hline \multirow[t]{2}{*}{2.0} & A.V. as percentage of B.V. & 100 & 94.6 & 78.4 & $\begin{array}{r}48.6 \\
48\end{array}$ & $\begin{array}{l}10.5 \\
44.9\end{array}$ & 31.9 & 25.4 \\
\hline & Percentage conversion to maltose & 0 & 1.2 & 2.0 & 3.6 & 6.8 & 10.0 & 8.4 \\
\hline \multirow[t]{2}{*}{2.5} & A.V. as percentage of B.V. & 100 & 94.3 & 83.0 & 67.9 & 59.4 & 41.5 & 32.1 \\
\hline & Percentage conversion to & 0 & $\mathbf{0}$ & 0 & 2.9 & 5.0 & 8.0 & 8.5 \\
\hline
\end{tabular}

1 The reaction mixture was composed of $2 \mathrm{ml}$. of buffer (pH 7.5), $1 \mathrm{ml}$. of starch solution, and $1 \mathrm{ml}$. of enzyme preparation. All assays were run at $22^{\circ} \mathrm{C}$.

concentrations tended to intensify the timelag between $Q$ enzyme and amylase. For example, at the $0.5-\mathrm{mg}$. $/ \mathrm{ml}$. level, amylase had converted 11.5 percent of the substrate to maltose within 5 minutes, whereas no maltose had appeared at the $2.5-\mathrm{mg}$. level prior to the 20 -minute sampling period (table 2). 
FFFECTS OF DIALYSIS AND ADDITIVES UPON Q-ENZYME ACTIVITY

Samples of the 0 to 35 -percent fraction were dialyzed against distilled water for periods ranging from 0 to 22 hours, and then tested for enzyme activity (table 3). Relatively little effect upon the enzyme was evident for any of the treatments. Following 6- and 10-hour treatments, blue-value decline was suppressed to from 65 to 70 percent of control values (table 3), but this was largely because of a reduction of amylase activity (fig. 10).

TABLE 3.-Effects of varying periods of dialysis upon the rate of starch hydrolysis by Q-enzyme preparation ${ }^{1}$

\begin{tabular}{|c|c|c|c|c|c|c|c|c|}
\hline \multirow{2}{*}{$\begin{array}{l}\text { Dialysis } \\
\text { time } \\
\text { (hours) }\end{array}$} & \multirow{2}{*}{ Starch transformation } & \multicolumn{7}{|c|}{ Results for indicated reaction time (minutes) } \\
\hline & & 0 & s & 10 & 20 & 30 & 40 & 50 \\
\hline \multirow[t]{2}{*}{0} & A.V. as percentage of $B . V$. & 100 & 92.2 & 84.4 & 62.2 & 57.3 & 51.9 & 54.1 \\
\hline & Percentagc conversion to maltose & 0 & 0 & 10.8 & 13.6 & 12.8 & 12.8 & 16.0 \\
\hline \multirow[t]{2}{*}{$1 / 2$} & A.V. as percentage of B.V. & 100 & 96.2 & 85.9 & 74.3 & 65.4 & 59.0 & 44.9 \\
\hline & Percentage conversion to maltose & 0 & 0 & 2.4 & 6.4 & 4.0 & 10.0 & 11.2 \\
\hline \multirow[t]{2}{*}{1} & A.V. as percentage of B.V. & 100 & 96.2 & 87.2 & 69.2 & 66.2 & 59.0 & 48.1 \\
\hline & Percentage conversion to maltose & 0 & .8 & 4.0 & 11.2 & 6.4 & 11.2 & 13.6 \\
\hline \multirow[t]{2}{*}{2} & A.V. as percentage of B.V. & 100 & 93.8 & 85.2 & 76.5 & 69.1 & 54.3 & 45.7 \\
\hline & Percentage conversion to maltose & 0 & .8 & 2.4 & 4.0 & 5.5 & 6.4 & 4.8 \\
\hline \multirow[t]{2}{*}{6} & A.V. as percentage of B.V. & 100 & 98.2 & 85.7 & 76.8 & 66.1 & 60.7 & 55.6 \\
\hline & Percentage conversion to maltose & 0 & 0 & 0 & 0 & 0 & 4.0 & 4.0 \\
\hline \multirow[t]{2}{*}{10} & A.V. as percentage of B.V. & 100 & 97.4 & 89.7 & 82.7 & 75.6 & 62.8 & 57.7 \\
\hline & Percentage conversion to maltose & 0 & 0 & .8 & 2.4 & 4.0 & 4.0 & 10.0 \\
\hline \multirow[t]{2}{*}{22} & A.V. as percentage of B.V. & 100 & 94.3 & 85.7 & 78.9 & 71.4 & 58.6 & 53.6 \\
\hline & Percentage conversion to maltose & 0 & 0 & 0 & .8 & 4.0 & 5.6 & 13.6 \\
\hline
\end{tabular}

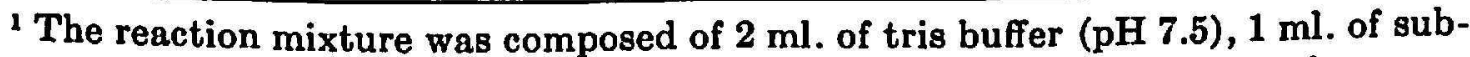
strate solution containing $4.0 \mathrm{mg}$. of soluble starch, and $1 \mathrm{ml}$. of dialyzed enzyme preparation.

Prolonging dialysis from 10 to 22 hours had no additional effect upon either enzyme.

A series of 12 reagents was tested as possible activators or inhibitors of the Q-enzyme-amylase complex (table 4). The only additive to effectively inhibit $\mathrm{Q}$ enzyme was lead $(0.25 \mathrm{mg}$. $\mathrm{Pb} / \mathrm{ml}$. of digest). This supports the findings of Barker et al. (4). Amylase was severely curtailed by copper $(0.025 \mathrm{mg}$. $\mathrm{Cu} / \mathrm{ml}$.), and citrate $(0.25 \mathrm{mg} . / \mathrm{ml}$.). Glucose, at the rate of 0.5 $\mathrm{mg} . / \mathrm{ml}$., also inhibited amylase. Fluoride $(0.25 \mathrm{mg} . / \mathrm{ml}$.) removed all traces of amylase activity with no apparent effects upon $\mathrm{Q}$ enzyme. Both $\mathrm{KCN}$ and DPN interferred in some manner with the starch-iodine color reaction. Since free iodine must react with starch to form the blue color, the additives might have brought about the reduction of iodine to iodide, or possibly 
blocked the sites at which iodine reacts with starch. In any event, an unusually strong reducing power appeared in the reaction mixture following the addition of KCN (table 4), suggesting an activator effect of KCN upon amylase. However, in the presence of so much cyanide it is questionable whether the increased reducing power represented enzymatic or chemical reactions.

The $\mathrm{Pb}$ and $\mathrm{F}$ ions were tested further at variable concentrations and at different $\mathrm{pH}$ levels (table 5). Fluoride $(0.25 \mathrm{mg} . / \mathrm{ml}$.) had completely inhibited amylase at $\mathrm{pH} 7.5$, and we wished to know whether the same effects could be achieved at $\mathrm{pH} 4.0$, where amylase was far more active. It was also desirable to learn whether $\mathrm{F}$ could serve as an inhibitor at $\mathrm{pH} 7.5$ in

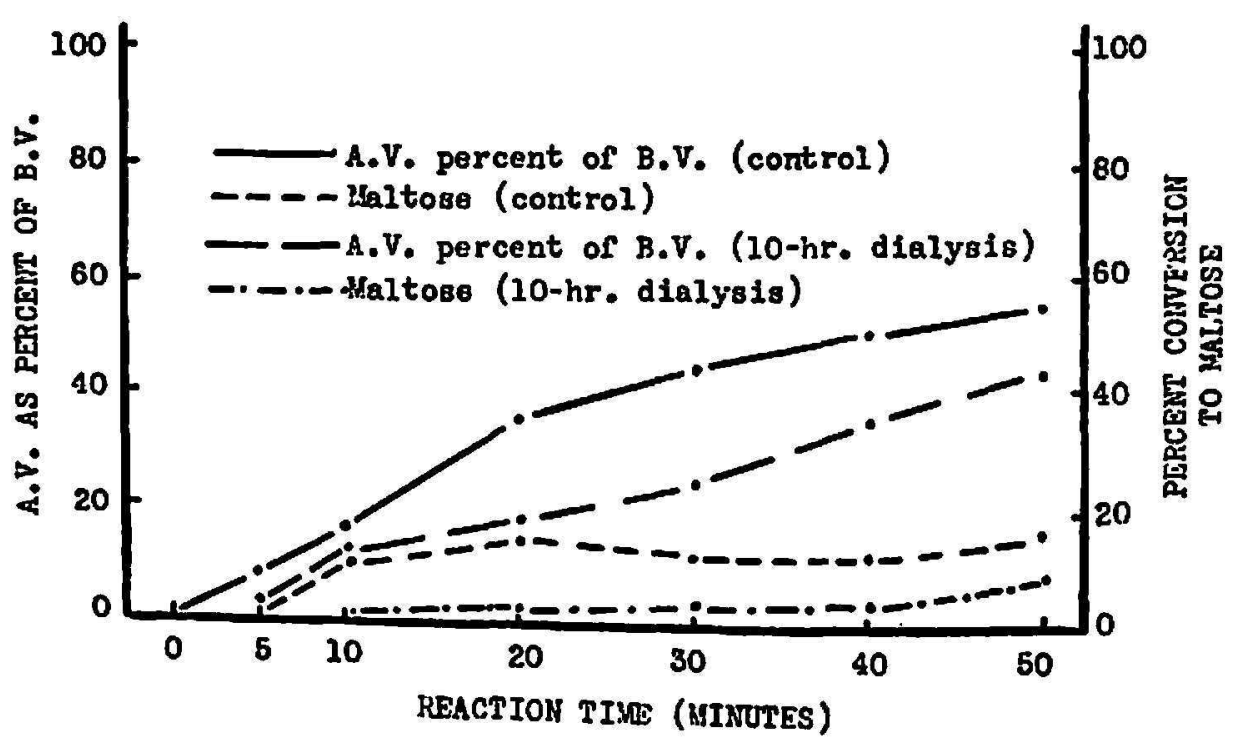

Fig. 10.-Changes in rate of blue-value decline following dialysis of Q-enzyme preparations against distilled water.

lesser concentrations than that initially tested. Lead had been only partly effective as an inhibitor at $0.25 \mathrm{mg}$. $/ \mathrm{ml}$, , and therefore the ion received additional tests at concentrations of 0.5 and $1.0 \mathrm{mg} . / \mathrm{ml}$.

None of the $\mathrm{F}$ concentrations tested was effective against amylase at $\mathrm{pH}$ 4.0 (table 5, expt. 1). On the other hand, an F supply as low as $0.005 \mathrm{mg} . / \mathrm{ml}$ severely suppressed the enzyme at $\mathrm{pH} 7.5$ (table 5, expt. 2). Inhibitory effects of $\mathbf{F}$ were most pronounced during the early phase of the reaction, and traces of maltose invariably appeared by the 40- and 50-minute sampling periods. Lead, at $0.5 \mathrm{mg}$. $/ \mathrm{ml}$., reduced blue-value decline from 80 to 28 percent in 50 minutes, while $1.0 \mathrm{mg} . / \mathrm{ml}$. of $\mathrm{Pb}$ further reduced the decline to 18 percent during an equivalent interval of time (table 5 , expt. 3 ).

The question arose as to whether or not $\mathrm{Pb}$ was acting as a competitive inhibitor, or as a noncompetitive inhibitor of the $Q$ enzyme. A series of tests was run in which the $\mathrm{Pb}$-inhibited reaction was measured against substrates 
TABLE 4.-Effects of additives upon the rate of starch hydrolysis by Q-enzyme preparation ${ }^{1}$

\begin{tabular}{|c|c|c|c|c|c|c|c|c|}
\hline \multirow{2}{*}{ ditive ${ }^{2}$} & \multirow{2}{*}{ arch transformatio } & \multicolumn{7}{|c|}{ Results in indicated reaction time (minutes) } \\
\hline & & o & 5 & 10 & 2 & 30 & 40 & 50 \\
\hline $\begin{array}{l}\tan \\
+\end{array}$ & $\begin{array}{l}\text { A.V. as percentage of } \\
\text { B.V. } \\
\text { Percentage conversion to } \\
\text { maltose }\end{array}$ & 100 & 92.4 & 80.3 & 2.4 & 50.0 & 12.0 & 13.6 \\
\hline $\begin{array}{l}\text { tande } \\
+K\end{array}$ & $\begin{array}{l}\text { A.V. as percentage of } \\
\text { B.V. } \\
\text { Percentage conversion to } \\
\text { maltose }\end{array}$ & 100 & $\begin{array}{l}100 \\
31.1\end{array}$ & 57.9 & $\begin{array}{l}100 \\
71.6\end{array}$ & $\begin{array}{l}100 \\
82.9\end{array} \mid$ & $\begin{array}{l}100 \\
81.6\end{array} \mid$ & $\begin{array}{l}100 \\
75.3\end{array}$ \\
\hline $\begin{array}{l}\text { and } \\
+1\end{array}$ & $\begin{array}{l}\text { A.V. as percentage of } \\
\text { B.V. } \\
\text { Percentage conversion to } \\
\text { maltose }\end{array}$ & 100 & 98.6 & 95.8 & 87.3 & 78.9 & 66.9 & 68.0 \\
\hline $\begin{array}{l}\operatorname{tand} \\
+1\end{array}$ & $\begin{array}{l}\text { A.V. as perc } \\
\text { B.V. } \\
\text { Percentage co } \\
\text { maltose }\end{array}$ & 100 & 95.6 & 84.0 & 65. & 58.0 & 45.6 & 38.4 \\
\hline $\begin{array}{l}\operatorname{tand} \\
+\end{array}$ & $\begin{array}{l}\text { A.V. as per } \\
\text { B.V. } \\
\text { Percentage co } \\
\text { maltose }\end{array}$ & 100 & 92.9 & 1.9 & 68.3 & 56.3 & 42.2 & 33.8 \\
\hline $\begin{array}{l}\text { tand } \\
+1\end{array}$ & $\begin{array}{l}\text { A.V. as percentage of } \\
\text { B.V. } \\
\text { Percentage conversion to } \\
\text { maltose }\end{array}$ & 100 & 95.0 & 80.6 & 65.5 & 56.1 & 46.0 & 33.8 \\
\hline $\begin{array}{c}\tan \\
+\end{array}$ & $\begin{array}{l}\text { A.V. as percentage of } \\
\text { B.V. } \\
\text { Percentage conversion to } \\
\text { maltose }\end{array}$ & 100 & $\begin{array}{c}95.9 \\
0\end{array}$ & 8 & 65.6 & 60.3 & 48.6 & 41.8 \\
\hline $\begin{array}{l}\operatorname{tand} \\
+S\end{array}$ & $\begin{array}{l}\text { A.V. as perce } \\
\text { B.V. } \\
\text { Percentage con } \\
\text { maltose }\end{array}$ & 100 & $\begin{array}{c}87.5 \\
0\end{array}$ & 79.8 & 63.3 & 46.8 & 33.8 & 24.5 \\
\hline $\begin{array}{l}\tan \\
+\end{array}$ & $\begin{array}{l}\text { A.V. as perce } \\
\text { B.V. } \\
\text { Percentage con } \\
\text { maltose }\end{array}$ & 100 & 89.3 & 77.1 & 62.8 & 48.6 & 35.7 & 27.1 \\
\hline+ & $\begin{array}{l}\text { A.V. as percentage of } \\
\text { B.V. } \\
\text { Percentage conversion to } \\
\text { maltose }\end{array}$ & 100 & $\begin{array}{c}90.1 \\
0\end{array}$ & 83.7 & 59.6 & 48.1 & 41.1 & 28.4 \\
\hline $\begin{array}{l}\text { tandard digest } \\
+\beta \text {-glycero- } \\
\text { phosphoric } \\
\text { acid }\end{array}$ & $\begin{array}{l}\text { A.V. as percentage of } \\
\text { B.V. } \\
\text { Percentage conversion to } \\
\text { maltose }\end{array}$ & 100 & $\begin{array}{c}92.9 \\
0\end{array}$ & 79.4 & 62.4 & 47.5 & $\begin{array}{l}34.7 \\
12.8\end{array}$ & 29.1 \\
\hline
\end{tabular}


TABLE 4.-Cont.

\begin{tabular}{|c|c|c|c|c|c|c|c|c|}
\hline \multirow{2}{*}{ Additive 2} & \multirow{2}{*}{ Starch transformation } & \multicolumn{7}{|c|}{ Results in indicated reaction time (minutes) } \\
\hline & & 0 & 5 & 10 & 20 & 30 & 40 & 50 \\
\hline $\begin{array}{l}\text { Standard digest } \\
\text { + ATP }\end{array}$ & $\begin{array}{l}\text { A.V. as percentage of } \\
\text { B.V. } \\
\text { Percentage conversion to } \\
\text { maltose }\end{array}$ & 100 & $\begin{array}{c}92.8 \\
0\end{array}$ & $\begin{array}{l}77.9 \\
16.8\end{array}$ & $\begin{array}{c}60.0 \\
0\end{array}$ & $\begin{array}{r}41.4 \\
4.0\end{array}$ & $\begin{array}{r}30.7 \\
8.0\end{array}$ & $\begin{array}{l}24.3 \\
13.6\end{array}$ \\
\hline $\begin{array}{l}\text { Standard digest } \\
+ \text { DPN }\end{array}$ & $\begin{array}{l}\text { A.V. as percentage of } \\
\text { B.V. } \\
\text { Percentage conversion to } \\
\text { maltose }\end{array}$ & 100 & $\begin{array}{r}100 \\
0\end{array}$ & $\begin{array}{l}100 \\
20.0\end{array}$ & $\begin{array}{r}100 \\
0\end{array}$ & $\begin{array}{r}100 \\
0\end{array}$ & $\begin{array}{r}100 \\
0\end{array}$ & $\begin{array}{r}100 \\
4.0\end{array}$ \\
\hline
\end{tabular}

1 Each reaction mixture was composed of $1 \mathrm{ml}$. of tris buffer (pH 7.5), $1 \mathrm{ml}$. of additive or water, $1 \mathrm{ml}$. of substrate solution containing $4 \mathrm{mg}$. of soluble starch, and $1 \mathrm{ml}$. of enzyme preparation. Additives were supplied in the following concentrations: $\mathrm{KCN}, \mathrm{Pb}, \mathrm{F}, \mathrm{S}$, acetate, citrate, $\beta$-glycerophosphoric acid, and ATP at $0.25 \mathrm{mg} . / \mathrm{ml}$. of digest; $\mathrm{Mo}$ and $\mathrm{Cu}$ at $0.025 \mathrm{mg} . / \mathrm{ml}$. of digest; glucose at 0.5 and DPN at $0.35 \mathrm{mg} . / \mathrm{ml}$. of digest. Each test was run at $22^{\circ} \mathrm{C}$.

2 The following reagents were used as additive sources: Lead acetate, sodium fluoride, sodium molybdate, cupric sulfate, sodium sulfate, sodium acetate, sodium citrate, sodium $\beta$-glycerophosphate, and disodium adenosine triphosphate.

ranging from 0.25 to $2.5 \mathrm{mg}$. $/ \mathrm{ml}$. The inhibitory action was partly removed by increased substrate concentrations (table 6), which is characteristic of competitive (reversible) inhibition. However, final confirmation must await further purification of the sugarcane enzyme. Attempts to suppress the action of amylase by fluoride were negative. A precipitate formed immediately when $\mathrm{F}$ and $\mathrm{Pb}$ were added to the same reaction mixture.

\section{EFFECTS OF VARIABLE TEMPERATURE}

Temperature studies covered a broad range from $7^{\circ} \mathrm{C}$. to $30^{\circ} \mathrm{C}$. (table 7). Of the temperature levels tested, $30^{\circ} \mathrm{C}$. was optimum for the $Q$ enzyme (fig. 11). Amylase was inactive at $7^{\circ} \mathrm{C}$. and achieved an activity maximum at $26^{\circ} \mathrm{C}$. Most of the Q-enzyme experiments described in this paper were conducted at room temperature $\left(22^{\circ} \mathrm{C}\right.$.) as a matter of convenience.

\section{Q ENZYME FROM VARIOUS TISSUE SOURCES}

Possibly the two most important decisions confronting a physiologist dealing with enzymes of sugarcane are 1 , determining which of the many tissues bear the catalysts in sufficient quantities for study, and 2, determining in which tissues the enzymes are represented while carrying out their most critical physiological roles. We chose to study the $Q$ enzyme in leaves +1 to +4 , because, from an enzymatic standpoint, our previous work had 
TABLE 5.-Effects of variable fuoride and lead concentrations upon the rate of starch hydrolysis by Q-enzyme preparation at $p H 4.0$ and $7.5^{1}$

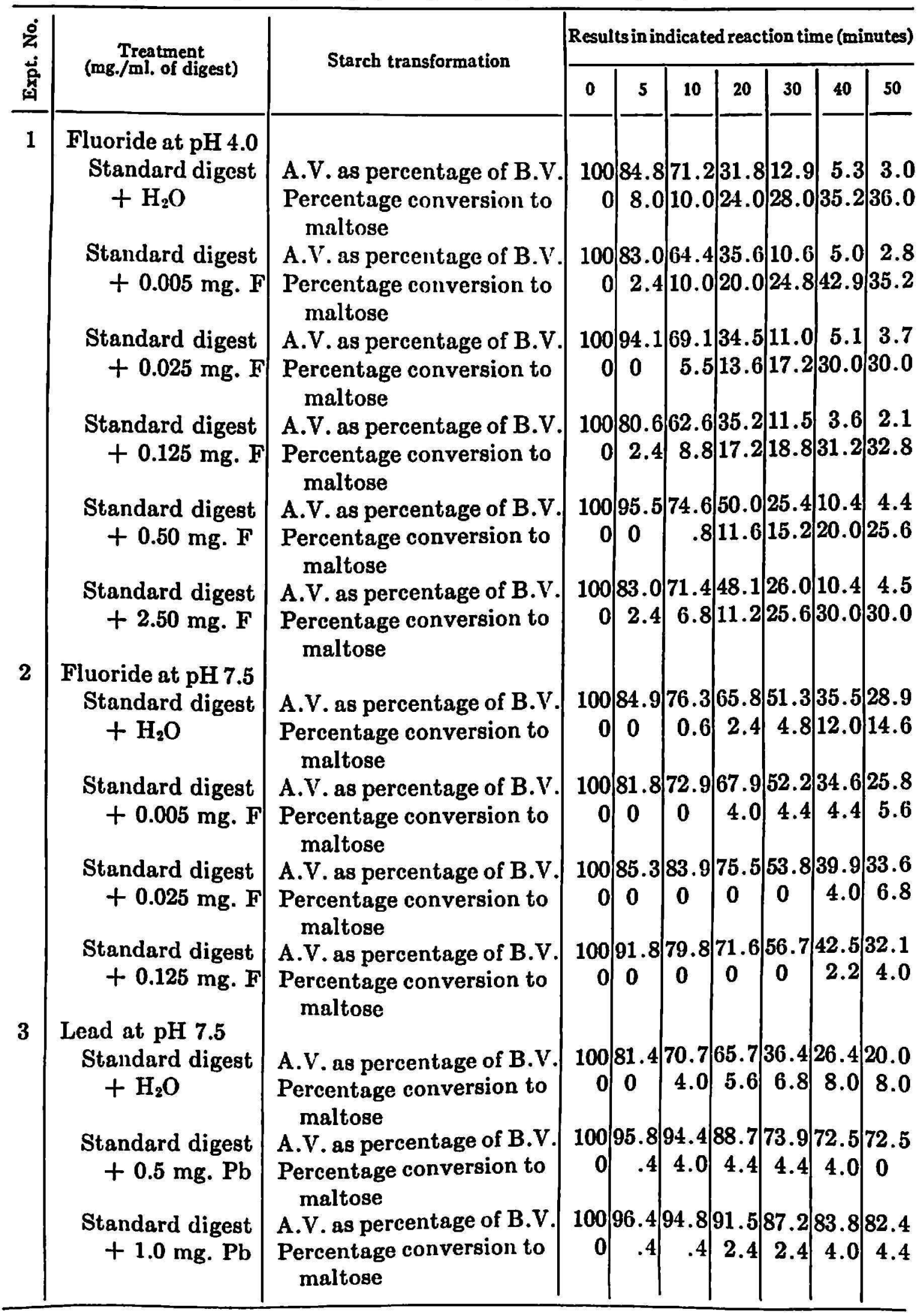

1 The reaction mixture for each of the assays was composed of $1 \mathrm{ml}$. of buffer ( $\mathrm{pH}$ 4.0 or 7.5$), 1 \mathrm{ml}$. of inhibitor solution, $1 \mathrm{ml}$. of substrate solution containing $4.0 \mathrm{mg}$. of soluble starch, and $1 \mathrm{ml}$. of enzyme preparation. Control treatments received distilled water in place of inhibitor. All tests were conducted at $22^{\circ} \mathrm{C}$. 
TABLE 6.-Effecls of increasing substrate concentration upon the lead-inhibited action of Q-enzyme preparation ${ }^{1}$

\begin{tabular}{|c|c|c|c|c|c|c|c|c|}
\hline \multirow{2}{*}{$\begin{array}{l}\text { Substrate } \\
\text { (mg./ml. of digest) }\end{array}$} & \multirow{2}{*}{ Starch transformation } & \multicolumn{7}{|c|}{ Results in indicated reaction time (minutes) } \\
\hline & & 0 & 5 & 10 & 20 & 30 & 40 & 50 \\
\hline $0.25 \mathrm{mg}$. + & A.V. as percentage of B.V. & 100 & 70.0 & 43.3 & 21.3 & 10.0 & 3.3 & 0 \\
\hline $\mathrm{H}_{2} \mathrm{O}$ & $\begin{array}{l}\text { Percentage conversion to } \\
\text { maltose }\end{array}$ & 0 & 0 & 3.1 & 9.2 & 15.4 & 26.2 & 38.5 \\
\hline $0.25 \mathrm{mg} .+0.5$ & A.V. as percentage of B.V. & 100 & 98.2 & 97.1 & 88.2 & 85.3 & 73.5 & 71. \\
\hline & $\begin{array}{l}\text { Percentage conversion to } \\
\text { maltose }\end{array}$ & 0 & $\mathbf{0}$ & 0 & 0 & 3.1 & 3.2 & 12. \\
\hline $0.50 \mathrm{mg} .+0.5$ & A.V. as percentage of B.V. & 100 & 91.7 & 87.5 & 81.9 & 79.9 & 68.0 & 61.1 \\
\hline $\mathrm{mg} \cdot \mathbf{P b}$ & $\begin{array}{l}\text { Percentage conversion to } \\
\text { maltose }\end{array}$ & 0 & 7.2 & 10.0 & 17.2 & 21.4 & 19.2 & 24.6 \\
\hline $1.0 \mathrm{mg} .+0.5$ & A.V. as percentage of B.V. & 100 & 89.8 & 88.4 & 77.5 & 73.6 & 61.1 & 58. \\
\hline $\mathrm{mg} \cdot \mathrm{Pb}$ & $\begin{array}{l}\text { Percentage conversion to } \\
\text { maltose }\end{array}$ & $\mathbf{0}$ & .8 & 2.4 & 1.8 & 1.8 & 2.5 & 5.1 \\
\hline $1.5 \mathrm{mg} .+0.5$ & A.V. as percentage of B.V. & 100 & 79.1 & 77.4 & 69.6 & 66.1 & 61.7 & 55. \\
\hline $\mathrm{mg}, \mathrm{Pb}$ & $\begin{array}{l}\text { Percentage conversion to } \\
\text { maltose }\end{array}$ & 0 & 0 & .5 & .6 & $\mathbf{0}$ & .5 & 2. \\
\hline $2.0 \mathrm{mg} .+0.5$ & A.V. as percentage of B.V. & 100 & 81.2 & 75.0 & 72.0 & 64.5 & 56.5 & 51.2 \\
\hline $\mathrm{mo}$ & $\begin{array}{l}\text { Percentage conversion to } \\
\text { maltose }\end{array}$ & 0 & $\mathbf{0}$ & & & 2.8 & 3.4 & 7.0 \\
\hline $2.5 \mathrm{mg} .+0.5$ & A.V. as percentage of B.V. & 100 & 82.7 & 82.0 & 75.0 & 70.4 & 57.1 & 47.2 \\
\hline mg. $\mathrm{Pb}$ & $\begin{array}{l}\text { Percentage conversion to } \\
\text { maltose }\end{array}$ & 0 & .9 & 1.3 & 2.2 & 3.2 & 4.5 & 5.6 \\
\hline
\end{tabular}

1 The reaction mixture for each assay was composed of $1 \mathrm{ml}$. of tris buffer $(\mathrm{pH}$ 7.5), $1 \mathrm{ml}$. of inhibitor solution containing $2.0 \mathrm{mg}$. of $\mathrm{Pb}, 1 \mathrm{ml}$. of soluble-starch solution representing 1.0 to $10.0 \mathrm{mg}$. of substrate, and $1 \mathrm{ml}$. of enzyme preparation. Each test was conducted at $22^{\circ} \mathrm{C}$.

TABLE 7.-Effects of varying temperature upon the rate of starch hydrolysis by Q-enzyme preparation ${ }^{1}$

\begin{tabular}{|c|c|c|c|c|c|c|c|c|}
\hline \multirow{2}{*}{$\begin{array}{c}\text { Tempera- } \\
\text { ture } \\
\text { ('C.) }\end{array}$} & \multirow{2}{*}{ Starch transformation } & \multicolumn{7}{|c|}{ Results in indicated reaction time (minutes) } \\
\hline & & 0 & 5 & 10 & 20 & 30 & 40 & 50 \\
\hline \multirow[t]{2}{*}{7} & A.V. as percentage of B.V. & 100 & 99.2 & 91.4 & 82.0 & 72.6 & 64.1 & 61.5 \\
\hline & Percentage conversion to maltose & 0 & 0 & 0 & 0 & .8 & 0 & .8 \\
\hline \multirow[t]{2}{*}{14} & A.V. as percentage of B.V. & 100 & 92.3 & 80.8 & 72.3 & 61.5 & 51.5 & 43.8 \\
\hline & Percentage conversion to maltose & 0 & & 2.4 & 3.2 & 5.6 & 2.4 & 3.2 \\
\hline \multirow[t]{2}{*}{22} & A.V. as percentage of B.V. & 100 & 84.8 & 69.7 & 54.5 & 41.7 & 26.5 & 22.0 \\
\hline & Percentage conversion to maltose & 0 & .9 & 2.4 & 4.0 & 8.8 & 11.2 & 14.0 \\
\hline \multirow[t]{2}{*}{26} & A.V. as percentage of B.V. & 100 & 78.7 & 59.5 & 32.3 & 19.8 & 11.8 & 6.6 \\
\hline & Percentage convergion to maltose & 0 & 3.2 & 4.0 & 8.0 & 16.0 & 15.2 & 19.2 \\
\hline \multirow[t]{2}{*}{30} & A.V. as percentage of B.V. & 100 & 72.1 & 49.2 & 28.7 & 13.9 & 5.7 & 4.9 \\
\hline & Percentage conversion to maltose & $\mathbf{0}$ & $\mathbf{0}$ & 2.4 & 8.8 & 6.8 & 10.0 & 16.0 \\
\hline
\end{tabular}

1 The reaction mixture for each assay was composed of $2 \mathrm{ml}$, of tris buffer $(\mathrm{pH}$ 7.5), $1 \mathrm{ml}$. of substrate solution containing $4 \mathrm{mg}$. of soluble starch, and $1 \mathrm{ml}$. of enzyme preparation. 
shown this area to be of paramount importance, both in number of systems present and in magnitude of reactions catalyzed.

To gain a clearer picture of the Q-enzyme distribution in sugarcane, a series of samples representing the meristem, leaves, sheaths, and cane tissues of 10-month-old plants were frozen and prepared for assay by methods identical with those already described for leaves. Results of the tests are summarized in table 8. Q-enzyme activity was maximum in leaves +6 and +7 (fig. 12). Amylase was highly active in meristem, accounting for virtually all of the starch-transforming properties of that tissue preparation. Very little Q-enzyme activity, and no amylase, could be detected in the 8

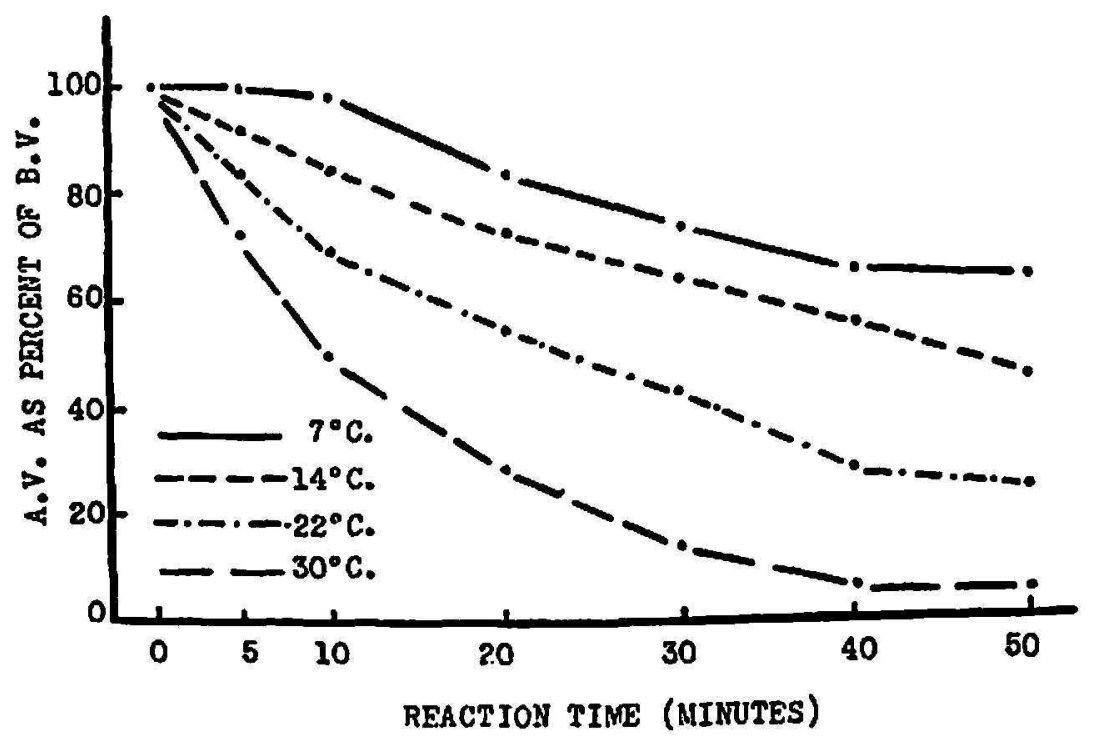

Fia. 11.-Effects of varying temperature upon the rate of blue-value suppression by Q-enzyme preparation.

to 10 internodes. Leaves +1 and +2 , sheaths +1 and +2 , and 8 to 10 nodes were roughly comparable with regard to $\mathrm{Q}$-enzyme activity.

The relative predominance of $Q$ enzyme in aged leaf tissue is a type of phenomenon we have not previously encountered with other sugarcane enzymes. An obvious implication is that the starch-forming sequence of cane may involve the translocation of amylose from sites of active phosphorylase in younger leaves and meristem ( 8 ), to older leaf tissues for the partial conversion to amylopectin. Since the Q-enzyme reaction is a more or less final step in starch formation, the most rapid degradation of the branched polysaccharide would appear to require translocation to meristem for the aid of $\alpha$-amylase, or to both meristem and younger leaves for $\beta$ amylase. 
TABLE 8.-Effects of different sample sources upon the rate of starch hydrolysis by Q-enzyme preparation 1

\begin{tabular}{|c|c|c|c|c|c|c|c|c|}
\hline \multirow{2}{*}{ Enzyme source } & \multirow{2}{*}{ Starch transformation } & \multicolumn{7}{|c|}{ Results in indicated reaction time (minutes) } \\
\hline & & $\mathbf{0}$ & 5 & 10 & 20 & 30 & 40 & 50 \\
\hline \multirow[t]{2}{*}{ Meristem } & A.V. as percentage of $B . V$. & 100 & 96.8 & 96.3 & 94.4 & 85.6 & 80.0 & 75.2 \\
\hline & $\begin{array}{l}\text { Percentage conversion to } \\
\text { maltose }\end{array}$ & 0 & 2.6 & 3.7 & 4.9 & 10.0 & 12.8 & 20.0 \\
\hline \multirow{2}{*}{$\begin{array}{l}\text { Leaves }+1 \text { and } \\
\quad+2\end{array}$} & A.V. as percentage of $B . V$. & 100 & 96.9 & 94.6 & 87.0 & 82.4 & 76.3 & 67.2 \\
\hline & $\begin{array}{l}\text { Percentage conversion to } \\
\text { maltose }\end{array}$ & 0 & 2.4 & 4.8 & 12.8 & 10.9 & 8.0 & 8.0 \\
\hline \multirow{2}{*}{$\begin{array}{l}\text { Leaves }+6 \text { and } \\
\quad+7\end{array}$} & A.V. as percentage of B.V. & 100 & 75.4 & 59.6 & 35.1 & 21.9 & 14.9 & 9.6 \\
\hline & $\begin{array}{l}\text { Percentage conversion to } \\
\text { maltose }\end{array}$ & 0 & 3.2 & 8.0 & 11.2 & 12.8 & 15.2 & 15.2 \\
\hline \multirow{2}{*}{ Sheaths +1} & A.V. as percentage of B.V. & 100 & 92.4 & 90.1 & 78.6 & 76.3 & 71.0 & 67.2 \\
\hline & $\begin{array}{l}\text { Percentage conversion to } \\
\text { maltose }\end{array}$ & 0 & 0 & 3.2 & 8.0 & .8 & .8 & 2.4 \\
\hline \multirow[t]{2}{*}{8 to 10 nodes } & A.V. as percentage of B.V. & 100 & 96.2 & 91.7 & 81.8 & 76.5 & 72.7 & 66.7 \\
\hline & $\begin{array}{l}\text { Percentage conversion to } \\
\text { maltose }\end{array}$ & 0 & 0 & 2.4 & 3.2 & 6.8 & 4.0 & 8.0 \\
\hline \multirow{2}{*}{$\begin{array}{l}8 \text { to } 10 \text { inter- } \\
\text { nodes }\end{array}$} & A.V. as percentage of $B . V$. & 100 & 100 & 99.2 & 98.5 & 95.4 & 92.2 & 90.0 \\
\hline & $\begin{array}{l}\text { Percentage conversion to } \\
\text { maltose }\end{array}$ & 0 & $\mathbf{0}$ & 0 & 0 & 0 & 0 & 0 \\
\hline
\end{tabular}

${ }_{1}^{1}$ The reaction mixture for each assay was composed of $2 \mathrm{ml}$. of tris buffer ( $\mathrm{pH}$ 7.5), $1 \mathrm{ml}$. of substrate solution containing $4 \mathrm{mg}$. of soluble starch, and $1 \mathrm{ml}$. of enzyme preparation. All tests were conducted at $22^{\circ} \mathrm{C}$.

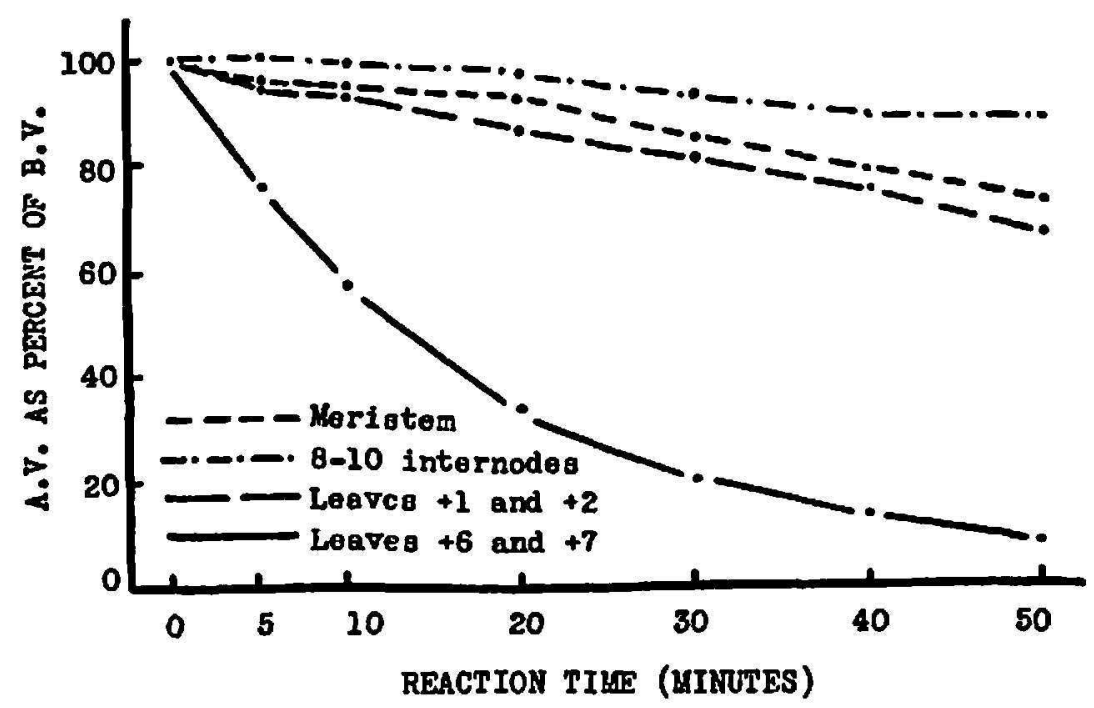

Fig. 12.-Rate of blue-value suppression by Q-enzyme preparations derived from various sugarcane tissues. 


\section{ELECTROPHORESIS EXAMINATION OF 0 TO 95- AND 0 TO 35-PERCENT FRACTIONS}

As was mentioned earlier, the 0 to 95 -percent fraction precipitated from bicarbonate extracts contained several highly active contaminating enzymes, including $\beta$-amylase, acid phosphatase, and starch phosphorylase. We do not know how many more enzymes of other types were also present. The transcendence of $\beta$-amylase, phosphatase, and part of the starch phosphorylase by salting only to 35 -percent saturation, had yielded a fraction in which $Q$ enzyme predominated over $\alpha$-amylase and traces of phosphoryl-

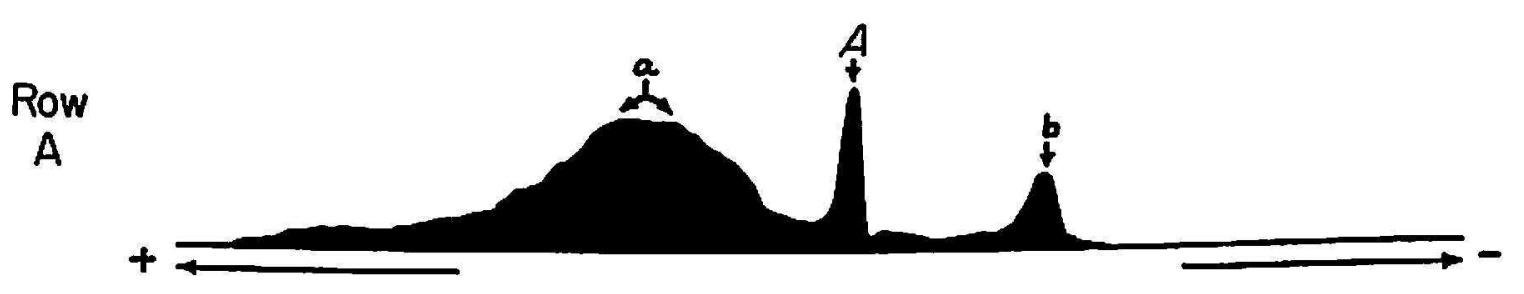

Row

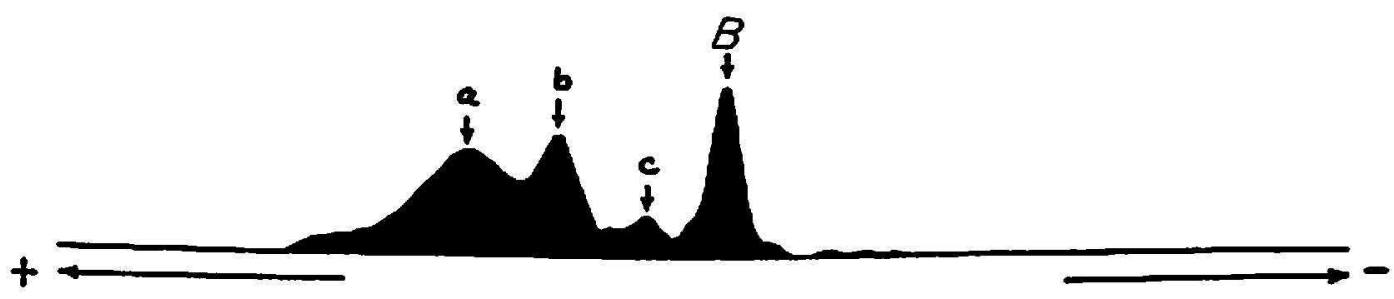

FIG. 13.-Tracings of protein migration patterns obtained by electrophoresis of enzyme fractions precipitated from bicarbonate extracts. Row A, Protein precipitated between 0 and 95 -percent saturation with ammonium sulfate; Row B, protein precipitated between 0 and 35-percent saturation.

ase. Again, enzyme tests alone gave us only a limited picture of the protein content. Electrophoresis studies were therefore applied to both the 0 to 95- and the 0 to 35 -percent fractions in an effort to separate the major protein components. Typical results are illustrated in figure 13.

After a 16-hour migration period, the 0 to 95-percent sample had separated into three distinct groups, figure 13 , row $\mathrm{A}$, including one fraction remaining immobile at the point of application, $A$, another, $\mathrm{b}$, which had migrated toward the cathode, and a third fraction, representing the bulk of the sample, which migrated as a single mass toward the anode. Groups $A$ and $a$ are characteristic of a protein sample containing too much material to be well separated without previous fractionation. The b group, apparently representing a body of positively charged protein, was not anticipated with 
a system buffered at $\mathrm{pH}$ 8.6. Under these conditions, the predominant protein charges should have been negative, which would insure migration towards the anode. The possibility was envisaged that dialysis had been insufficient to remove some contaminant cation, such as $\mathrm{Pb}$, which then migrated with a protein otherwise immobilized at its isoelectric point. Yet repeated experiments after prolonged hydrolysis failed to remove this component. The best explanation we can put forward at the moment is that among the sugarcane-leaf proteins there is a fraction possessing an iso-

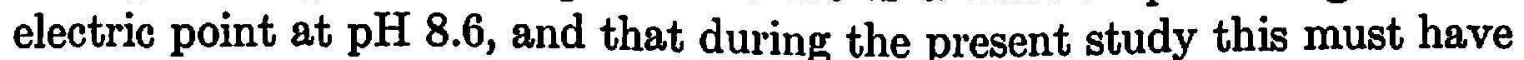
migrated freely to either side of the application point, independent of either electrode. In figure 13, A, the counterpart of $b$ would have been masked by component a.

The 0 to 35-per cent fraction, row B, was separated into four distinct components including an immobile area at the point of application, $A$, a barely mobile component, c, representing less than 8 percent of the sample, and two relatively distinct components, $a$ and $b$, which together made up 61 percent of the sample. Component $b$ of the 0 to 95 -percent fraction did not reappear. It is possible that this protein represents the $\beta$-amylase or phosphatase, or both, which had been present in the 0 to 95 -percent fraction. The protein groups a, b, and c, figure 13 , row $B$, have not been tested for enzyme activity, but it is suspected that they represent $Q$ enzyme, $\alpha$-amylase, and phosphorylase, respectively.

\section{SIGNIFICANCE OF Q ENZYME IN SUGARCANE}

With the possible exception of the variety Uba (20), growers and processors have felt little concern over the phenomenon of starch formation in sugarcane. Nevertheless, a broad survey of cane-leaf enzymes revealed that amylase is a most voracious catalyst in cane, and that its suppression could be correlated with increased sucrose content (1). Further studies have shown that starch phosphorylase, amylase, hexokinase, and acid phosphatase are intimately active in determining the fate of glucose-1-phosphate, and therefore in determining the capacity of the plant to form sucrose (3). The more thoroughly we understand the properties, behavior patterns, and personal idiosyncrasies of such systems, the greater will be our capacity to slant their reactions toward a maximum production of sugar. The Qenzyme, $\alpha$-amylase complex encountered during the present study confirms a critical link in the scheme by which starch is synthesized and degraded in sugarcane.

The following sequence was used previously to account for the relationship of free glucose to the processes of sucrose and starch biosynthesis: 


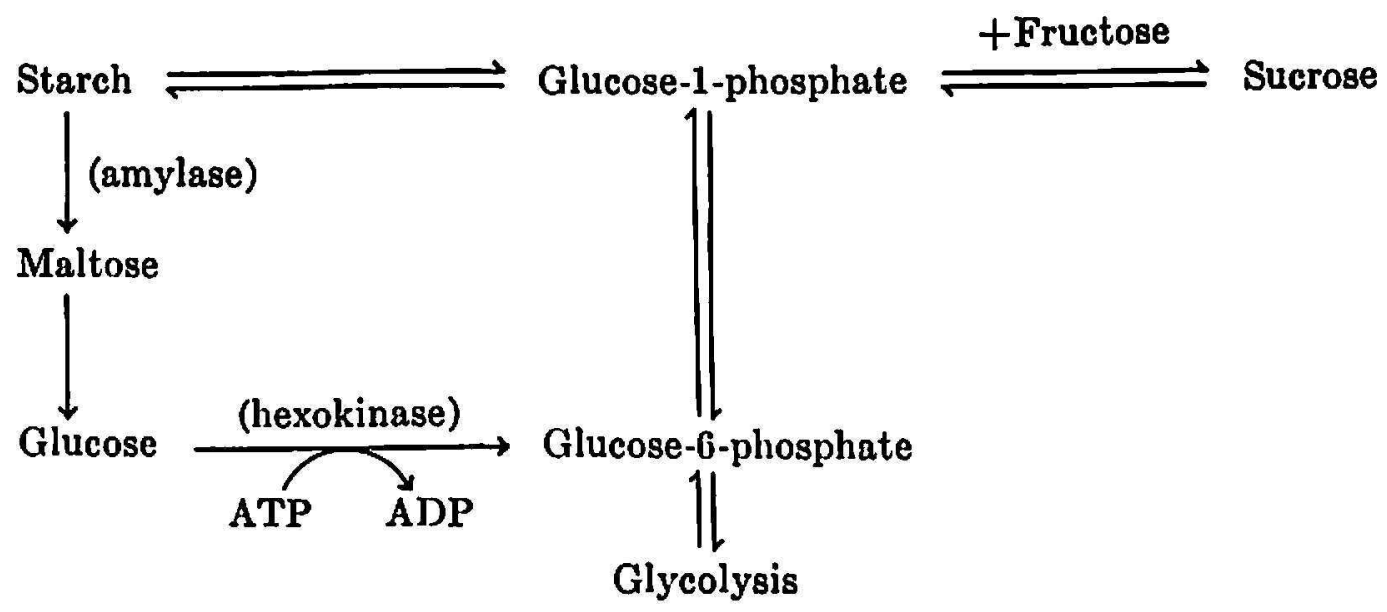

The recognition of cane-leaf amylase and hexokinase alone provided a basis for bringing forth the above sequence. Our present understanding of the Q-enzyme, $\alpha$-amylase complex of sugarcane can now be incorporated into the scheme as follows:

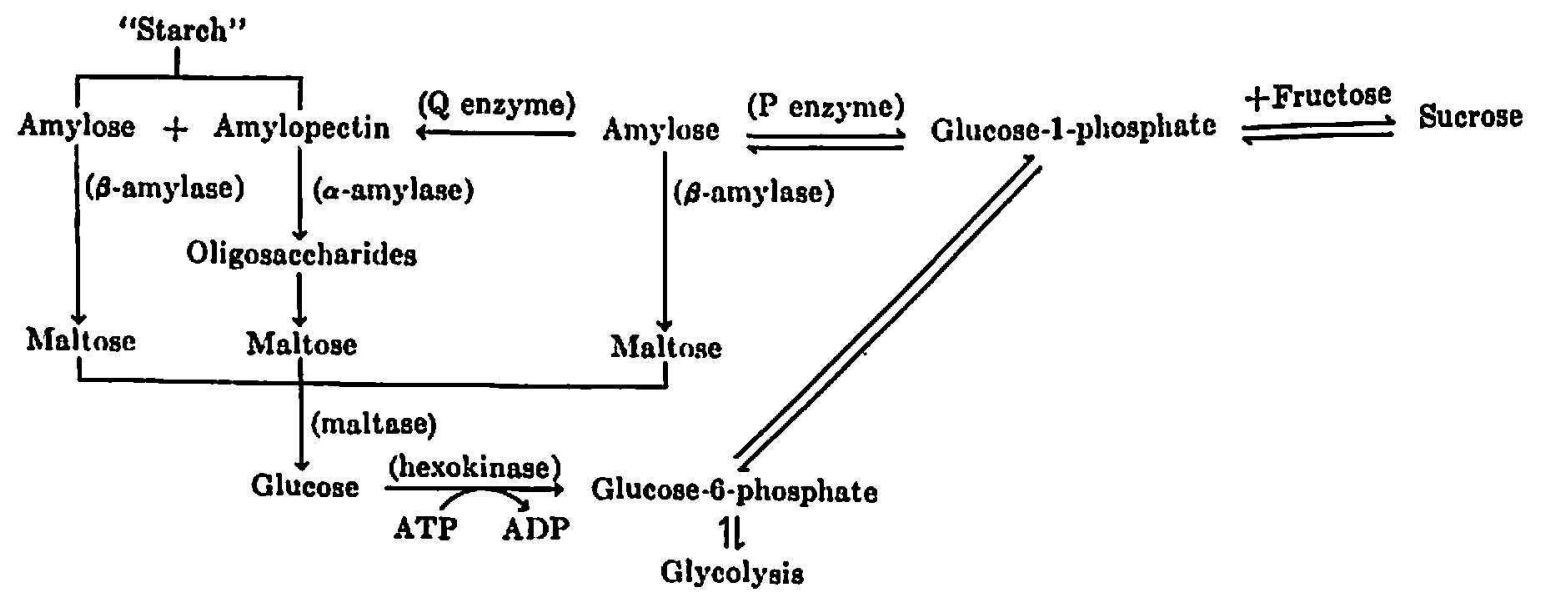

\section{SUMMARY}

A polysaccharide branching factor, apparently identical with the $Q$ enzyme of potatoes, has been extracted from sugarcane leaves and partly characterized. Procedures used successfully by other workers to isolate the $\mathrm{Q}$ enzyme from potato extracts failed to yield the branching system free from other catalysts of sugarcane. A preparation satisfactory for characterization studies was obtained by precipitating protein from water extracts with lead acetate, eluting the precipitate with bicarbonate solution, and fractionating the bicarbonate extract with ammonium sulfate. The $Q$ enzyme was precipitated between 0 and 35 -percent saturation, at pH 7.2 and $22^{\circ} \mathrm{C}$.

The 0 to 35-percent fraction was virtually free of acid phosphatase and $\beta$-amylase. Traces of starch phosphorylase (P enzyme) were present but caused no difficulty in the absence of phosphate buffers. However, an 
amylase of the $\alpha$ type was present, which interferred seriously with $Q$ enzyme measurements in acid media, particularly in the area of $\mathrm{pH} 4$ to 5 .

$\mathrm{Q}$ enzyme was moderately active between $\mathrm{pH} 6.5$ and 9.0 , with optimum $\mathrm{pH}$ at approximately 7.5. The $\alpha$-amylase was very weak at $\mathrm{pH}$ values higher than 6.5.

Soluble potato starch was employed as substrate throughout these studies. Optimum concentration was 2.0 to $2.5 \mathrm{mg}$. $/ \mathrm{ml}$. of digest. $\alpha$-amylase was most active against $0.5 \mathrm{mg} . / \mathrm{ml}$. of digest.

$\mathrm{Q}$ enzyme experienced an 85-percent inhibition by lead ions, $0.5 \mathrm{mg} . / \mathrm{ml}$, when acting upon a substrate level of $0.25 \mathrm{mg} . / \mathrm{ml}$. of digest. Increasing the starch concentration to $2.5 \mathrm{mg}$./ml. partly removed the lead effects, indicating that the inhibition was competitive. Fluoride, $0.025 \mathrm{mg} . / \mathrm{ml}$., completely eliminated $\alpha$-amylase activity at $\mathrm{pH} 7.5$, but had little effect at $\mathrm{pH}$ 4.0. $\alpha$-amylase was also suppressed by copper.

Dialysis against distilled water had little effect upon $Q$ enzyme, but strongly retarded amylase after 6 and 10 hours. Twenty-two-hour dialysis caused no further changes in either enzyme.

The most favorable temperature tested with $\mathrm{Q}$ enzyme was $30^{\circ} \mathrm{C}$., although the system was fairly active at temperatures as low as $7^{\circ} \mathrm{C}$. $\alpha$-amylase was not active at $7^{\circ} \mathrm{C}$., but achieved the maximum rate measured at $26^{\circ} \mathrm{C}$.

A series of sugarcane tissues was tested for $Q$ enzyme, including meristem, leaves +1 and +2 , leaves +6 and +7 , sheaths +1 and $+2,8$ to 10 nodes, and 8 to 10 internodes. Activity was far greater in leaves +6 and +7 than any other tissue tested. $\alpha$-amylase was most active in the meristem preparations.

Electrophoresis studies showed that the 0 to 35 -percent fraction was composed of at least three distinct protein constituents. These were presumed to represent $Q$ enzyme, $\alpha$-amylase, and starch phosphorylase.

The significance of $Q$ enzyme in sugarcane is briefly discussed. A diagram is presented to illustrate the role of the polysaccharide branching factor in relation to the starch -and sucrose-forming pathways.

\section{RESUMEN}

De la hoja de la caña de azúcar se extrajo un factor de la polisacarida, aparentemente idéntico a la enzima $Q$ de la papa, cuyos caracteres se han descrito parcialmente. Los procedimientos usados con éxito por otros investigadores para aislar la enzima $Q$ de los extractos de papa, no lograron separar el sistema ramificafor de otros agentes catalizadores de la caña de azúcar. Obtúvose una preparación satisfactoria para hacer estudios descriptivos de los caracteres precipitando proteína de extractos acuosos con acetato de plomo, lixiviando el precipitado con una solución de bicarbonato 
y fraccionando el extracto de bicarbonato con sulfato amónico. La enzima $Q$ se precipitó a una saturación entre 0 y 35 por ciento, a un pH de 7.2 y una temperatura de $22^{\circ} \mathrm{C}$.

La fracción de 0 a 35 por ciento estuvo virtualmente libre de fosfatasa ácida y $\beta$-amilasa. Había trazas de fosforilasa de almidón (enzima $\mathrm{P}$ ); pero ésta no caus6 dificultad alguna en la ausencia de fosfatos amortiguadores. No obstante, estaba presente una amilasa del tipo $\alpha$, la cual interfirí seriamente con las medidas de la enzima $Q$ en un medio ácido particularmente en el área de un $\mathrm{pH}$ de 4 a 5 .

La enzima $Q$ estuvo moderadamente activa entre los pH 6.5 y 9.0, llegando a su 6ptimo a un $\mathrm{pH}$ de 7.5 aproximadamente. La acción de la amilasa- $\alpha$ fue muy débil en los valores de $\mathrm{pH}$ mayores de 6.5.

Se empleó almidón soluble de papa como substrato en todos estos estudios. La concentración 6 ptima fue de 2.0 a $2.5 \mathrm{mg} . / \mathrm{ml}$. de digesto. La amilasa- $\alpha$ estuvo más activa en presencia de $0.5 \mathrm{mg} . / \mathrm{ml}$. de digesto.

En la enzima $Q$ hubo una inhibición de un 85 por ciento debido a la acción de iones de plomo $(0.5 \mathrm{mg} . / \mathrm{ml}$.) cuando actuaba sobre un nivel de substrato de $0.25 \mathrm{mg} . / \mathrm{ml}$. de digesto. Aumentando la concentración de almidón a $2.5 \mathrm{mg} . / \mathrm{ml}$., se eliminaron parcialmente los efectos del plomo, indicando que la inhibición fue competitiva. El fluoruro $(0.025 \mathrm{mg} . / \mathrm{ml}$.) eliminó completamente la actividad de la $\alpha$-amilasa a un $\mathrm{pH}$ de 7.5, pero tuvo poco efecto a un $\mathrm{pH}$ de 4.0. La $\alpha$-amilasa fue también suprimida por la acción del cobre.

La diálisis en presencia de agua destilada tuvo poco efecto sobre la enzima $Q$, pero retard6 marcadamente la amilasa después de 6 y de 10 horas. Una diálisis de 22 horas no causó cambios adicionales en ninguna de las enzimas.

La temperatura más favorable de las que se probaron con la enzima $Q$, fue de $30^{\circ} \mathrm{C}$., aunque el sistema estuvo bastante activo a temperaturas tan bajas como de $7^{\circ} \mathrm{C}$. La $\alpha$-amilasa no estuvo activa a los $7^{\circ} \mathrm{C}$, pero alcanz6 el grado más alto de actividad que se ha medido a los $26^{\circ} \mathrm{C}$.

Se analizaron varios tejidos de la caña de azúcar en busca de la enzima $\mathrm{Q}$, incluyendo el meristemo; las hojas $+1 \mathrm{y}+2$, hojas $+6 \mathrm{y}+7$; yaguas +1 y +2 ; nudos del 8 al 10 y entrenudos del 8 al 10 . La actividad fue mucho mayor en las hojas $+6 y+7$ que en ningún otro tejido analizado. La amilasa- $\alpha$ estuvo más activa en las preparaciones con tejidos del meristemo.

Estudios de electrofóresis demostraron que la fracción de 0 a 35 por ciento estaba compuesta de por lo menos tres distintos ingredientes de la proteína. Se presume que representaban la enzima $Q, \alpha$-amilasa y fosforilasa de almidon.

Aquí se discute brevemente la significación de la enzima $Q$ en la caña de azúcar. Se presenta un diagrama para ilustrar el papel que desempeña el 
factor ramificador de la polisacarida en relación con los "caminos" que toma en la formación del almidón y la sacarosa.

\section{LITERATURE CITED}

1. Alexander, A. G., Sucrose-enzyme relationships in immature sugarcane as affected by varying levels of nitrate and potassium supplied in sand culture, $J$. Agr. Univ. P.R. 48 (3): 165-231, 1964.

2. - Physiological studies of enzymes catalyzing the synthesis and hydrolysis of sucrose, starch, and phosphorylated hexose in sugarcane, J. Agr. Univ. P.R. 49 (1): 60-75, 1965.

3. - Behavior of enzymes governing starch- and sucrose-forming pathways in two sugarcane varieties supplied with variable nitrate and phosphate in sand culture, J. Agr. Univ. P.R. 49 (2): 153-75, 1965.

4. Barker, S. A., Bourne, E. J., and Peat, S., The enzymatic synthesis and degradation of starch, pt. IV, The purification and storage of the $Q$ enzyme of the potato, J. Chem. Soc. S: 1705-17, 1959.

5. Bourne, J. E., Haworth, N., Macy, A., and Peat, S., The amylolytic degradation of starch: A revision of the hypothesis of sensitization, J. Chem. Soc. 2: 924-30, 1948.

6. Cori, C. F., Colowick, S. P., and Cori, G. T., The isolation and synthesis of glucose-1-phosphoric acid, J. Biol. Chem. 121: 465-77, 1937.

7. Cori, G. T., and Cori, C. F., The kinetics of the enzymatic synthesis of glycogen from glucose-1-phosphate, J. Biol. Chem. 185: 733-56, 1940.

8. Fruton, J. S., and Simmonds, S., General Biochemistry, John Wiley \& Sons, Inc., New York, N.Y., 1959.

9. Gilbert, G. A., and Swallow, A. J., The influence of ions on the activity of $Q$ enzyme, J. Chem. Soc. 4: 2849-52, 1949.

10. Gilbert, G. A., and Patrick, A. D., Enzymes of the potato concerned in the synthesis of starch, I, The separation and crystallization of $Q$ enzyme, Biochem. $J .51: 181-6,1952$.

11. Hanes, C. S., The breakdown and synthesis of starch by an enzyme system from pea seeds, Proc. Roy. Soc. London, B 128: 421-50, 1939-40.

12. - Reversible formation of starch from glucose-1-phosphate catalyzed by potato phosphorylase, Proc. Roy. Soc. London, B 129: 174-208, 1940.

13. Hobson, P. N., Whelan, W. J., and Peat, S., The enzymatic synthesis and degradation of starch, pt. XIV, R-enzyme, J. Chem. Soc. 2: 1451-9, 1951.

14. Larner, J., and McNickle, C. M., Gastrointestinal digestion of starch, I, The action of oligo-1,6-glucosidase on branched saccharides, J. Biol. Chem. 815: 723-36, 1955.

15. Larner, J., and Gillespie, R. E., Gastrointestinal digestion of starch, II, Properties of the intestinal carbohydrases, J. Biol. Chem. 28s: 709-26, 1956.

16. Meyer, K., The chemistry of glycogen, Advances in Enzymol., s: 109-35, 1943.

17. Peat, S., The biological transformations of starch, Advances in Enzymol., 2: 33975, 1951.

18. Peat, S., Whelan, W. J., Hobson, P. N., and Thomas, G. J., The enzymatic synthesis and degradation of starch, pt. XIX, The action of R-enzyme on glycogen, $J$. Chem. Soc. 4: 4440-5, 1954.

19. Sumner, J. B., Dinitrosalicylic acid: A reagent for the estimation of sugar in normal and diabetic urine, $J$. Biol. Chem. 47: 5-9, 1921.

20. Wood, G. G., Some factors influencing starch in sugarcane, Proc. S. African Sugar Technol. Assn. (36th Annual Cong.) 123-35, 1962. 